\title{
Revision of Bairdiella (Sciaenidae: Perciformes) from the western South Atlantic, with insights into its diversity and biogeography
}

\author{
Alexandre Pires Marceniuk ${ }^{1,2}$, Eduardo Garcia Molina ${ }^{3}$, Rodrigo Antunes Caires ${ }^{4}$, \\ Matheus Marcos Rotundo ${ }^{5}$, Wolmar Benjamin Wosiacki ${ }^{1}$, Claudio Oliveira ${ }^{2}$
}

The sciaenid genus Bairdiella comprises a group of relatively small fishes found in inshore waters and estuaries of the western Atlantic and eastern Pacific. Despite recent analyses of the phylogenetic relationships of Bairdiella, there has been no comprehensive revision of the alpha taxonomy of the species of the genus. Bairdiella ronchus from the western Atlantic, has a complex taxonomic history, with four junior synonyms recognized. Based on morphological and molecular evidence, this study indicates that $B$. ronchus represents a species complex. The species is therefore redescribed and its geographic range is redefined. Bairdiella veraecrucis, which is currently recognized as a junior synonym of $B$. ronchus, is revalidated, and a new species of the genus is described from the Atlantic coast of Brazil. Finally, inferences are made on the diversity and biogeography of the $B$. ronchus species complex.

Key words: Biogeographic patterns, New species, Species complex, Taxonomy, Western Atlantic.

O gênero Bairdiella compreende um grupo de peixes relativamente pequenos encontrados em águas costeiras e estuários do Atlântico ocidental e leste do Pacífico. Apesar das análises recentes das relações filogenéticas de Bairdiella, não houve revisão abrangente da taxonomia alfa das espécies do gênero. Bairdiella ronchus, do Atlântico ocidental, tem uma história taxonômica complexa, com quatro sinônimos juniores reconhecidos. Baseado em evidências morfológicas e moleculares, este estudo indica que $B$. ronchus representa um complexo de espécies. A espécie é, portanto, redescrita e seu alcance geográfico é redefinido. Bairdiella veraecrucis, atualmente reconhecida como sinônimo júnior de B. ronchus, é revalidada, e uma nova espécie do gênero é descrita na costa atlântica do Brasil. Finalmente, inferências são feitas sobre a diversidade e biogeografia do complexo de espécies de B. ronchus.

Palavras-chave: Atlântico ocidental, Coplexo de espécies, Espécie nova, Padrões Biogeograficos, Taxonomia.

\section{Introduction}

The Sciaenidae is one of the largest families of Perciformes, with approximately 300 species, found in the coastal zones of tropical and temperate regions worldwide (Chao, 1978, 1986; Sasaki, 1989; Fricke et al., 2018a). Most species are marine, some are euryhaline, and are able to adapt to a wide range of salinity, while six genera are restricted to freshwater habitats (Casatti, 2002). Abundant demersal species of the family are important as fishery resources, and play a relevant role in both nearshore and estuarine commu- nities. However, several questions on the alpha taxonomy and biogeography of the family remain unanswered (Lo et al., 2014).

Bairdiella Gill, 1861 comprises a group of relatively small fishes (TL up to $350 \mathrm{~mm}$ ) found in inshore waters and estuaries of the western Atlantic (WA) and eastern Pacific (EP). The five currently recognized species of Bairdiella are found in tropical and subtropical coastal waters (Chao, 1995, 2003): B. armata Gill, 1863 (EP), B. chrysoura (Lacepède, 1802) (WA), B. ensifera (Jordan \& Gilbert, 1882) (EP), B. icistia (Jordan \& Gilbert, 1882) (EP), and B. ronchus

\footnotetext{
${ }^{1}$ Museu Paraense Emílio Goeldi, 66040-170 Belém, PA, Brazil. (APM) a_marceniuk@hotmail.com, Dhttps://orcid.org/0000-0003-4286-0482 (corresponding author),(WBW) wolmar@museu-goeldi.br, Dhttps://orcid.org/0000-0002-4013-8501

${ }^{2}$ Departamento de Morfologia, Instituto de Biociências, Universidade Estadual Paulista, 18618-000, Botucatu, SP, Brazil. (CO) claudio@ibb.unesp.br, Ohttps://orcid.org/0000-0002-4143-7212

${ }^{3}$ Instituto de Biología de la Universidad Nacional Autónoma de México, 04510 Ciudad de México, Mexico. biolgarciame@gmail.com, Dhttps://orcid.org/0000-0002-7234-2806

${ }^{4}$ Museu de Zoologia da Universidade de São Paulo, 04263-000 São Paulo, SP, Brazil. rodricaires@yahoo.com.br, Dhttps://orcid. org/0000-0002-9918-3972

${ }_{5}^{5}$ Acervo Zoológico da Universidade Santa Cecília, 11045-907 Santos, SP, Brazil. mmrotundo@unisanta.br, Dhttps://orcid. org/0000-0003-1886-5320
} 
(Cuvier, 1830) (WA). The monophyly of the genus is well supported (Chao, 1978), and its close relationship with Corvula Jordan \& Eigenmann, 1889, Odontoscion Gill, 1862, Ophioscion Gill, 1863, Elattarchus Jordan \& Evermann, 1896, and Stellifer Oken, 1817, is supported by both morphological (Sasaki, 1989) and molecular evidence (Vinson et al., 2004; Barbosa et al., 2014; Santos et al., 2016). There is not, however, consensus on the phylogenetic relationships among those genera inside the assemblage (Lo et al., 2014).

Different studies have investigated monophyly and phylogenetic relationships of the Bairdiella, but the alpha-taxonomy of the species is complex. Four junior synonyms are currently recognized in B. ronchus, described based on specimens collected in Venezuela, Dominican Republic, Cuba and Suriname: Corvina subaequalis Poey, 1875 (Cuba, type locality), Corvina fulgens Vaillant \& Bocourt, 1883 (El Salvador, type locality), Sciaena bedoti Regan, 1905 (Cuba, type locality), and Bairdiella veraecrucis Jordan \& Dickerson, 1908 (Mexico, type locality) (Fricke et al., 2018b), which have been defined without the systematic examination of the type-specimens or representative material (Chao, 1978).

The objective in the present work is to revise and redefine the taxonomic status of the B. ronchus species complex using morphological and DNA barcoding data. Additionally, we provide inferences on the diversity and biogeography of the recognized species of this group.

\section{Material and Methods}

Morphological data. Measurements were taken with either a ruler and recorded to the nearest millimeter, or with dial callipers and recorded to the nearest $0.1 \mathrm{~mm}$. The following measurements were obtained through orthogonal projections using a ruler: Caudal-peduncle length $(\mathrm{CPl})$, from the posterior basal margin of the last anal-fin ray to the end of the hypural plate; Distance from snout to anal fin (SAd), from the tip of the snout to anterior basal portion of first anal-fin spine; Distance from snout to dorsal fin (SDd), from the tip of the snout to anterior basal portion of first dorsal-fin spine; Distance from the tip of the snout to the pectoral fin (SPd), from the tip of the snout to anterior basal portion of first pectoral-fin ray; Head length $(\mathrm{Hl})$, from the tip of the snout to the end of the operculum, including its membranous portion; Snout length (S1), from the tip of the snout to the anterior margin of the orbit; Standard length (SL), from the tip of the snout to the end of the hypural plate. The remaining measurements were taken point-to-point: Anal-fin height (Ah), from its insertion to the end of the longest spine; Anal-fin base length (Abl), from the anterior basal margin of the first spine to the posterior basal margin of the last ray; Body depth (Bd), measured as the vertical distance at the anterior basal margin of the first dorsal-fin ray and anterior basal margin of first pelvic-fin ray; Body width $(\mathrm{Bw})$, measured as the greatest body width at the pectoral girdle region; Caudal-peduncle height $(\mathrm{CPh})$, measured as the least depth of caudal peduncle region; Dorsal fin height (Dh), from basal insertion to tip of longest spine; Dorsal fin base length (Dbl), from the anterior basal margin of its first dorsal-fin spine to posterior basal margin of last dorsal-fin ray; Head depth (Hd), the greatest vertical height of the head at the posterior margin of the operculum; Maxillary height $(\mathrm{Mh})$, greatest vertical height of the maxilla at the mouth angle; Maxillary length (Ml), greatest distance between anterior and posterior margins of maxilla; Mouth width (Mw), external distance between mouth angles; Orbital diameter (Od), greatest orbital width; Interorbital distance (IOd), the greatest distance between the upper margins of the orbit; Post-orbital length (POl), the distance from the posterior margin of the orbit to the end of the membranous posterior portion of operculum; Pectoral fin height $(\mathrm{Ph})$, from its basal insertion to tip of longest ray. Counts were taken of the elements of the dorsal, anal and pectoral fins, as well as the number of gill rakers on the first gill-arch, the number of scales with pores on lateral line, and the number of scales above and below the lateral line, at the level of the dorsal fin. Whenever possible, the sex of the specimens was determined through the examination of the gonads under magnification.

A Principal Component Analysis (PCA) was employed to analyze the log-transformed measurements in a matrix of co-variance in the computer program PAST 3.19. The dataset was standardized prior to the analyses. The broken-stick model was used as the stopping rule in the PCA, and the variables were interpreted based on the highest and lowest loading values for the selected axes. The values that were constant were excluded from the PCA, leaving $\mathrm{Abl}, \mathrm{Bd}, \mathrm{CPh}, \mathrm{CPl}, \mathrm{Dh}$, $\mathrm{Hl}$, Od, and Ph (Fig. 1). Based on the PCA analysis, bivariate scatterplots were used to show diagnostic morphological difference of the morphometric data, and ranges were used in the analysis of the meristic data. In the text, measurements are given as percentages of the standard length (SL), unless otherwise stated. The diagnosis of the western Atlantic species was based on direct examination of specimens, while the diagnosis of the eastern Pacific species was based on the literature (Chao, 1978, 1995, 2003; Castro-Aguirre et al., 1999; McEachran, Fechhelm, 2005) and the diagnostic characters available at the Smithsonian Tropical Research Institute (https://biogeodb.stri.si.edu/sftep/en/gallery/genus/1424 and https://biogeodb.stri.si.edu/caribbean/en/gallery/genus/1424).

The specimens examined are deposited in the following institutions: Acervo Zoológico da Universidade Santa Cecília (AZUSC), Santos, São Paulo, Brazil; Colección Nacional de Peces del Instituto de Biología de la Universidad Nacional Autónoma de México (CNPE-IBUNAM), Ciudad de México, México; Laboratório de Biologia e Genética de Peixes da Universidade Estadual de São Paulo (LBP-UNESP), Botucatu, São Paulo, Brazil; Museu Paraense Emílio Goeldi (MPEG), Belém, Pará, Brazil; Museu de Zoologia da Universidade de São Paulo (MZUSP) in São Paulo, São Paulo State, Brazil; and National Museum of Natural History, Smithsonian Institution (USNM), Washington, D.C., U.S.A. Photographs of specimens deposited in the Muséum National d'Histoire Naturelle (MNHN), Paris, France were also used in this study. 


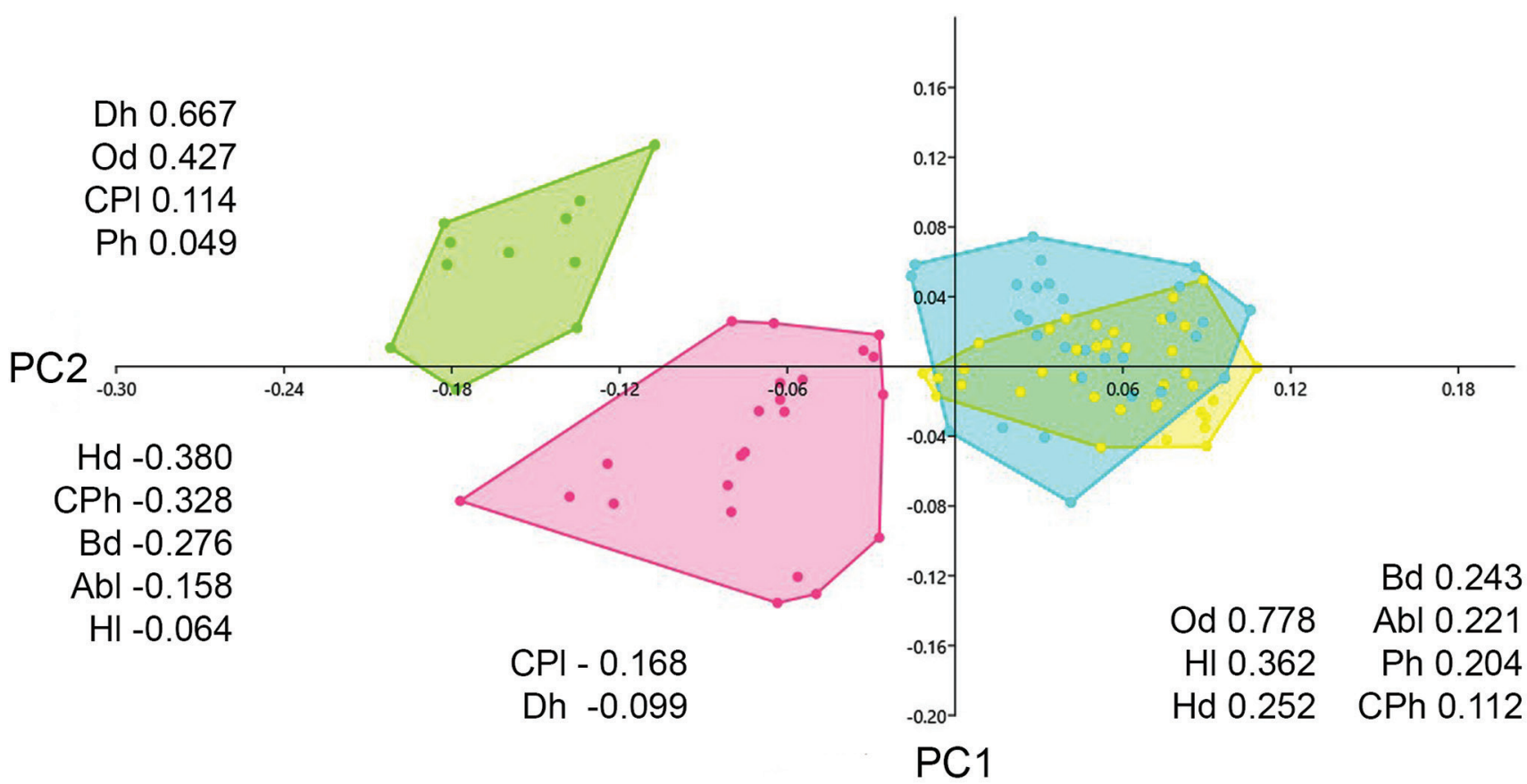

Fig. 1. Scatterplots of the principal components (PC1 and $\mathrm{PC} 2)$ obtained from the analysis of nine morphometric variables in Bairdiella goeldi sp. nov. (yellow $=$ north-northeastern Brazilian lineage. light blue $=$ southeastern lineage), B. ronchus (red), and B. veraecrucis (green). Abl. = Anal-fin base length; $\mathrm{Bd} .=$ Body depth; $\mathrm{CPh} .=$ Caudal-peduncle height; $\mathrm{Hd} .=\mathrm{Head}$ depth; Hl. = Head length; Od. = Orbital diameter; Ph. = Pectoral-fin height.

Molecular data. Partial cytochrome oxidase $\mathrm{C}$ subunit I (COI) sequences (652 bp) were obtained from three specimens of Corvula sanctaeluciae Jordan, 1890 (Venezuela), a single specimen each of $B$. ronchus (Venezuela), B. veraecrucis (Mexico), and B. chrysoura (Mexico), and 10 specimens of the new species of Bairdiella, described herein, from Brazil. Additionally, 28 sequences were obtained in GenBank (Tab. 1). Vouchers and tissues of the specimens sequenced herein are deposited in the fish collection of the LBP-UNESP, MPEG, and CNPE-IBUNAM.

DNA Extraction and Sequencing. Genomic DNA was isolated from fins or muscle tissues of the specimens with a DNeasy Tissue Kit (Qiagen), according to the manufacturer instructions. Amplifications were performed in a total volume of $12.5 \mu \mathrm{l}$ with $1.25 \mu \mathrm{l}$ of $10 \mathrm{X}$ buffer $(10 \mathrm{mM}$ Tris$-\mathrm{HCl}+15 \mathrm{mM} \mathrm{MgCl} 2), 0.5 \mu \mathrm{dNTPs}(200 \mathrm{nM}$ of each), 0.5 $\mu 1$ each $5 \mathrm{mM}$ primer (FishF2, FishR2 described in Ward et al., 2005), $0.05 \mu$ l Platinum ${ }^{\circledR}$ Taq Polymerase (Invitrogen 5units/ $\mu \mathrm{l}), 1 \mu \mathrm{l}$ template DNA (12 ng), and $8.7 \mu \mathrm{lddH} 2 \mathrm{O}$. The PCR reactions consisted of $30-40$ cycles, $30 \mathrm{~s}$ at $95^{\circ} \mathrm{C}$, $15-30 \mathrm{~s}$ at $48-54^{\circ} \mathrm{C}$ (depending on each species), and 45 $\mathrm{s}$ at $72^{\circ} \mathrm{C}$. All PCR products were first visually identified on a $1 \%$ agarose gel and then purified using ExoSap-IT® (USB Corporation) following manufacturer instructions. The purified PCR products were sequenced using the "Big DyeTM Terminator v 3.1 Cycle Sequencing Ready Reaction Kit" (Applied Biosystems), purified again by ethanol precipitation and loaded on an automatic sequencer 3130-Genetic Analyzer (Applied Biosystems).
Phylogenetic analyses. Consensus sequences from forward and reverse strands were obtained using Geneious Pro 8.1.8 (Kearse et al., 2012). Alignments were generated using the MUSCLE algorithm (Edgar, 2004) under default parameters. After alignment, the matrix was checked by eye for any obvious misalignments, and to detect potential cases of sequencing errors. A quality control step was included in our workflow to detect contamination, paralogous copies or pseudogenes. After that, the presence of stop codons was checked using Geneious. Nucleotide variation, substitution patterns, the best substitution model and genetic distances were examined using the Mega 6.06 (Tamura et al., 2013).

For the species delimitation and consequent identification of Operational Taxonomy Units (OTUs), we used the traditional molecular identification, and the General Mixed Yule Coalescent model (GMYC). The lognormal relaxed molecular clock tree was estimated using BEAST v.1.8.3 (Drummond et al., 2012) since the Generalized Mixed Yule Coalescent model (GMYC) requires an ultrametric tree. However, the tree was not time-calibrated. The nucleotide evolutionary model used for estimating the ultrametric tree was the GTR model with Gamma distribution. Briefly, we used Bayesian inference of phylogeny with relaxed lognormal clock and Birth-death speciation process rate on an arbitrary timescale. A random tree was used as a starting tree for the Markov chain Monte Carlo searches. Eight chains were run simultaneously for $100,000,000$ generations and a tree was sampled every 1000th generation. The above analysis was performed twice. The distribution of log-likelihood scores was examined to determine the stationary phase for each search and decide whether extra 
runs were required to achieve convergence, using the program Tracer 1.6 (Drummond et al., 2012). All sampled topologies beneath the asymptote $(2,500,000$ generations) were discarded as part of a burn-in procedure, and the remaining trees were used to construct a 50\% majority-rule consensus tree in TreeAnnotator v1.8.3 (Drummond et al., 2012).

Tab. 1. Genbank number of sequences used and added in the present study of Bairdiella chrysoura, B. goeldi sp. nov., B. ronchus, B. veraecrucis, Corvula macrops, Corvula sanctaeluciae, Odontoscion dentex (Cuvier, 1830). The sampling location to the abbreviations corresponds to ISO3166 country codes.

\begin{tabular}{|c|c|c|c|c|}
\hline Species & LBP & Tissue & Country & Genbank \\
\hline B. chrysoura & & & US & JQ842394 \\
\hline B. chrysoura & & & US & JQ842397 \\
\hline B. chrysoura & & & US & KF929637 \\
\hline B. chrysoura & & & US & JQ841845 \\
\hline B. chrysoura & & & US & JQ842392 \\
\hline B. chrysoura & & & US & JQ842393 \\
\hline B. chrysoura & & & US & JQ842395 \\
\hline B. chrysoura & & & US & JQ842396 \\
\hline B. goeldi sp. nov. & 19376 & 76171 & BR & MG813777 \\
\hline B. goeldi sp. nov. & 19376 & 76172 & BR & MG813773 \\
\hline B. goeldi sp. nov. & 19376 & 76173 & BR & MG813775 \\
\hline B. goeldi sp. nov. & 19376 & 76174 & BR & MG813776 \\
\hline B. goeldi sp. nov. & 22258 & 84204 & $\mathrm{BR}$ & MG820456 \\
\hline B. goeldi sp. nov. & 22204 & 84692 & BR & MG820457 \\
\hline B. goeldi sp. nov. & 10071 & 40530 & BR & JQ365241 \\
\hline B. goeldi sp. nov. & 10014 & 46914 & BR & JQ365242 \\
\hline B. goeldi sp. nov. & 10014 & 46915 & $\mathrm{BR}$ & JQ365243 \\
\hline B. goeldi sp. nov. & 10071 & 40524 & $\mathrm{BR}$ & JX124740 \\
\hline B. goeldi sp. nov. & & & $\mathrm{BR}$ & KJ907229 \\
\hline B. goeldi sp. nov. & & & BR & KJ907230 \\
\hline B. goeldi sp. nov. & & & BR & KJ907231 \\
\hline B. goeldi sp. nov. & & & $\mathrm{BR}$ & KJ907232 \\
\hline B. ronchus & 6436 & 29508 & VE & MG813778 \\
\hline B. veraecrucis & & & MX & MG813774 \\
\hline C. macrops & & & & KP722712 \\
\hline C. macrops & & & & KP722711 \\
\hline C. sanctaeluciae & 6435 & 29507 & $\mathrm{VE}$ & MG813779 \\
\hline C. sanctaeluciae & 6435 & 29505 & VE & MG813780 \\
\hline C. sanctaeluciae & 6435 & 29506 & $\mathrm{VE}$ & MG813781 \\
\hline C. sanctaeluciae & & & MX & GU225153 \\
\hline O. dentex & & & $\mathrm{TT}$ & JQ842975 \\
\hline O. dentex & & & $\mathrm{TT}$ & JQ842974 \\
\hline O. dentex & & & $\mathrm{BR}$ & KJ907237 \\
\hline O. dentex & & & $\mathrm{TT}$ & JQ841302 \\
\hline O. dentex & & & $\mathrm{TT}$ & JQ841300 \\
\hline O. dentex & & & $\mathrm{TT}$ & JQ841298 \\
\hline O. dentex & & & $\mathrm{TT}$ & JQ841299 \\
\hline O. dentex & & & BR & KJ907236 \\
\hline O. dentex & & & $\mathrm{BR}$ & KJ907235 \\
\hline
\end{tabular}

We performed the single threshold method with standard parameters (interval $=\mathrm{c}(0.10)$ ), because changing the upper and lower limit of the scaling parameters had no noticeable effect on the results. This analysis was developed in version 3.0.0 of of $\mathrm{R}$ ( $\mathrm{R}$ Development Core Team 2013) with the package "splits" (Species Limits by Threshold Statistics) (http://r-forge.r-project.org/projects/splits). The "gmyc" function in R optimizes the likelihood function described in Pons et al. (2006) which specifies the likelihood of branching intervals assuming between species branching according to a Yule model, or assuming evenly increasing or decreasing net speciation rates towards the present; coalescence within species according to a neutral coalescent; or with evenly increasing or decreasing rates of coalescent branching towards the ancestral node.

The calibration point was chosen based on the Sciaenidae phylogeny of Lo et al. (2015), where Bairdiella, Corvula and Odontoscion belong to a monophyletic group originated at 10.2 million years. These dates were implemented in BEAST v.1.8.0 (Drummond et al., 2012) with a normal prior offset of 10.2 and standard deviation of 0.4 . A lognormal relaxed clock (uncorrelated) model and a birth-death process to calibrate our phylogenetic tree were employed. Furthermore, GTR plus gamma and invariant values for nucleotide substitution model was used. All clade-age estimates are presented as the mean and 95\% highest posterior density (HPD) values. The analysis was run for 100 million generations and sampled every $1,000^{\text {th }}$ generation. Stationarity and sufficient mixing of parameters (ESS > 200) were checked using Tracer 1.6 (Drummond et al., 2012). All sampled topologies beneath the asymptote $(25,000,000$ generations) were discarded as part of a burn-in procedure. The remaining trees were used to build a 50\% majority-rule consensus tree using TreeAnnotator v1.8.3 (Drummond et al., 2012).

\section{Results}

The categorization and naming of a species can be regarded as a hypothesis on the evolutionary relationships and distinguishability of different groups of organisms (Costa-Silva et al., 2016). In the present study, the acknowledgment of B. ronchus, B. veraecrucis and Bairdiella sp. new as distinct species by both morphological evidence (Principal Components Analysis, Fig. 1) and DNA barcoding information (Fig. 2, Tabs 2, 3). The time-calibrated phylogeny obtained in BEAST (Fig. 2) indicates that $B$. veraecrucis diverged from the lineage that includes $B$. ronchus and $B$. goeld $i$ sp. nov. at $1.57 \pm 0.93$ mya, while $B$. ronchus and $B$. goeldi sp. nov. diverged at $0.85 \pm 0.76$ mya. The molecular separation of $B$. goeld $i$ sp. nov., B. rochus, and B. veraecrucis is corroborated by the GMYC analysis (see S1 - Available only as online supplementary file accessed with the online version of the article at http://www.scielo.br/ni). 


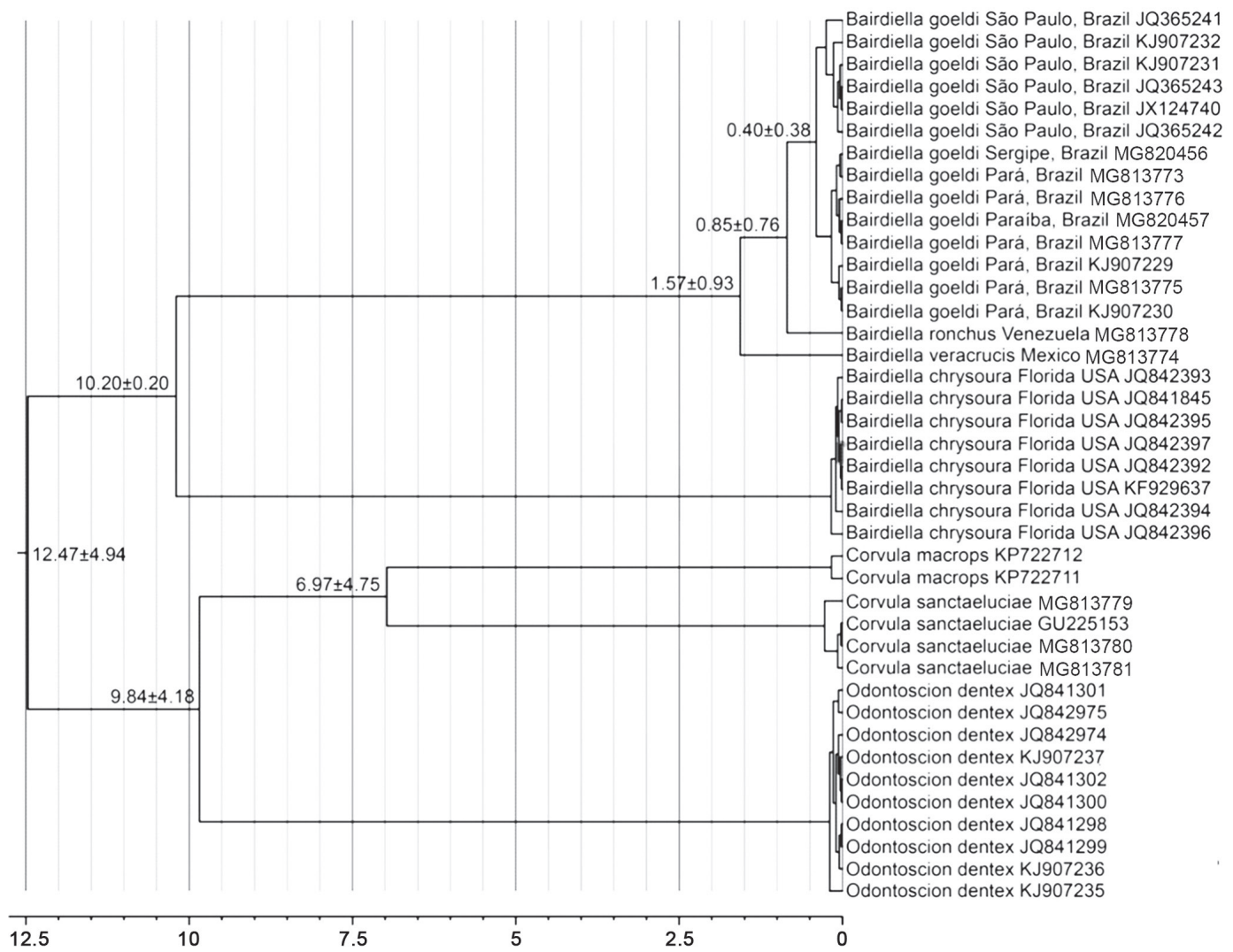

Fig. 2. Time-calibrated phylogeny obtained using BEAST (100 million generations) indicating the divergence over time in Bairdiella. The molecular clock was calibrated based on the data of Lo et al. (2015), which indicated that Bairdiella. Corvula, and Odontoscion belong to a monophyletic clade that originated 10.2 million years ago. Scale $=$ millions of years before present. Numbers at nodes $=$ estimated age $\pm 95 \%$ HPD.

Tab. 2. Measurements of Bairdiella goeldi sp. nov., B. ronchus, and B. veraecrucis expressed as percentages of standard length.

\begin{tabular}{|c|c|c|c|c|c|c|c|c|c|c|c|}
\hline & \multicolumn{5}{|c|}{ B. goeldi } & \multicolumn{3}{|c|}{ B. ronchus } & \multicolumn{3}{|c|}{ B. veraecrucis } \\
\hline & type & $\mathrm{N}$ & Mean & Range & $\mathrm{N}$ & Mean & Range & type & $\mathrm{N}$ & Mean & Range \\
\hline Standard length $(\mathrm{mm})$ & 190.0 & & & $90-198$ & 24 & & $79-241$ & 201 & 11 & & $125-236$ \\
\hline Head length & 30.6 & 60 & 28.9 & $27.6-34.0$ & 24 & 28.9 & $25.4-32.5$ & 23.9 & 10 & 25.0 & $23.7-27.8$ \\
\hline Head depth & 25.2 & 60 & 29.0 & $22.1-34.2$ & 24 & 28.4 & $25.4-30.0$ & 23.9 & 11 & 25.4 & $23.7-30.0$ \\
\hline Pos-orbital length & 17.5 & 58 & 18.0 & $16.8-19.1$ & 24 & 18.5 & $16.8-19.4$ & 16.8 & 11 & 17.6 & $16.8-19.0$ \\
\hline Orbital diameter & 9.0 & 53 & 9.1 & $8.1-10.3$ & 22 & 6.8 & $5.2-8.1$ & 5.7 & 11 & 6.5 & $5.7-7.7$ \\
\hline Interorbital distance & 7.3 & 56 & 7.0 & $6.5-7.7$ & 2 & 7.2 & $6.8-7.5$ & & & & \\
\hline Snoutlength & 6.1 & 53 & 6.4 & $5.3-7.4$ & 22 & 6.8 & $4.9-8.9$ & 5.3 & 11 & 7.4 & $5.3-8.6$ \\
\hline Mouthwidth & 10.1 & 53 & 10.0 & $8.7-11.5$ & 21 & 10.7 & $8.4-13.6$ & 11.9 & 11 & 10.0 & 8.4-12.1 \\
\hline Maxillary length & 32.0 & 54 & 32.6 & $30.3-36.4$ & 2 & 32.9 & $32.4-33.3$ & & & & \\
\hline Maxillary height & 12.1 & 53 & 12.6 & $11.9-13.4$ & 2 & 13.3 & $12.9-13.7$ & & & & \\
\hline Body depth & 30.8 & 60 & 32.7 & $28.9-35.9$ & 24 & 31.2 & 29.2-33.9 & 29.9 & 11 & 28.4 & $25.8-31.8$ \\
\hline Bodywidth & 16.4 & 58 & 17.0 & $14.2-20.0$ & 24 & 17.7 & $13.8-21.5$ & 19.4 & 11 & 16.0 & $13.8-19.4$ \\
\hline Distance from snout to dorsal fin & 32.9 & 54 & 31.6 & $27.4-35.2$ & 2 & 32.2 & $30.7-34.2$ & 35.4 & 11 & 36.0 & $34.2-37.5$ \\
\hline Dorsal-fin length & 14.7 & 60 & 15.8 & $13.9-17.7$ & 24 & 15.5 & $11.1-18.4$ & 16.0 & 10 & 18.2 & $16.7-20.0$ \\
\hline Dorsal-fin base length & 55.0 & 56 & 56.1 & $52.1-60.3$ & 24 & 54.4 & $50.7-57.3$ & 53.9 & 11 & 53.4 & $48.7-56.5$ \\
\hline Distance from snout to pectoral fin & 28.7 & 58 & 29.7 & $25.5-33.8$ & 24 & 31.1 & $27.9-34.5$ & 29.6 & 11 & 30.2 & 28.4-31.6 \\
\hline Pectoral fin length & 22.5 & 55 & 22.3 & $19.5-24.3$ & 20 & 20.4 & $17.6-23.1$ & 22.7 & 11 & 20.7 & $19.1-20.8$ \\
\hline Distance from snout to anal fin & 73.2 & 58 & 72.4 & $68.0-75.5$ & 24 & 73.3 & $68.7-76.7$ & 76.8 & 10 & 71.1 & $66.4-74.9$ \\
\hline Anal-fin length & 20.8 & 57 & 21.2 & $18.2-24.2$ & 22 & 20.9 & $18.6-23.7$ & 21.1 & 11 & 22.2 & $19.6-23.8$ \\
\hline Anal-fin base length & 12.0 & 60 & 11.7 & $10.1-13.4$ & 21 & 11.3 & $10.0-12.8$ & 10.9 & 11 & 10.4 & $9.1-11.5$ \\
\hline Caudal-peduncle height & 10.8 & 56 & 11.0 & $9.6-12.2$ & 24 & 11.1 & 10.4-11.9 & 10.4 & 11 & 9.9 & $8.7-10.8$ \\
\hline Caudal-peduncle length & 17.1 & 57 & 19.1 & $16.2-21.4$ & 23 & 20.2 & $18.2-22.2$ & 19.0 & 10 & 20.9 & $20.0-21.9$ \\
\hline
\end{tabular}


Tab. 3. Meristic data of Bairdiella goeldi sp. nov., $B$. ronchus, and B. veraecrucis. Lateral line scales (A); scales above lateral line (B); scales below the lateral line (C); dorsal-fin rays (D); pectoral-fin rays (E); anal-fin rays $(\mathbf{F})$; gill rakers on the first gill $\operatorname{arch}(\mathbf{G})$.

\begin{tabular}{|c|c|c|c|c|c|c|c|c|c|c|c|}
\hline & $\mathbf{A}$ & 48 & 49 & 50 & 51 & 52 & 53 & 54 & 55 & & \\
\hline B. goeldi sp. nov. & & 2 & 4 & 9 & 15 & 7 & 8 & 5 & 6 & & \\
\hline B. ronchus & & & 3 & 12 & 5 & 2 & 2 & & & & \\
\hline B. veraecrucis & & & 2 & 5 & 3 & 2 & & & & & \\
\hline & B & 8 & 9 & 10 & C & 9 & 10 & 11 & 12 & & \\
\hline B. goeldi & & 21 & 42 & 11 & & 25 & 28 & 14 & 3 & & \\
\hline B. ronchus & & 11 & 12 & 1 & & 3 & 13 & 8 & & & \\
\hline B. veraecrucis & & 6 & 6 & & & & 7 & 5 & & & \\
\hline & D & 21 & 22 & 23 & 24 & $\mathbf{E}$ & 15 & 16 & 17 & 18 & \\
\hline B. goeldi & & 9 & 29 & 24 & 8 & & 2 & 27 & 33 & 10 & \\
\hline B. ronchus & & & 3 & 11 & 10 & & & 9 & 13 & 2 & \\
\hline B. veraecrucis & & & 1 & 6 & 5 & & & 4 & 7 & 1 & \\
\hline & $\mathbf{F}$ & 8 & 9 & 10 & $\mathbf{G}$ & 21 & 22 & 23 & 24 & 25 & 26 \\
\hline B. goeldi & & 23 & 9 & 1 & & & 9 & 16 & 21 & 16 & 7 \\
\hline B. ronchus & & 22 & & & & & 11 & 9 & 3 & 1 & 1 \\
\hline B. veraecrucis & & 12 & & & & 1 & 3 & 6 & 2 & & \\
\hline
\end{tabular}

In addition, two distinct molecular lineages were recognized in Bairdiella sp. new along the Brazilian coast, one from the north-northeastern coast of Brazil and the other from its southwestern coast (Figs. 2, 3). Although these lineages are differentiated by two exclusive COI mutations (Tab. 3), the genetic distance between them is very small $(0.007 \pm 0.003)$, reflecting a very recent divergence, of only $0.40 \pm 0.38$ mya (Fig. 2). The GMYC analysis did not support the recognition of these lineages as distinct species (Supplementary Material), and no morphological differences separate them. Given those results we consider the two Brazilian lineages, or two local populations of Bairdiella sp. new to be an example of the so-called gray zone, within which alternative species concepts come into conflict (De Queiroz, 2007). A more systematic discussion of the areas of hybridization and secondary contact between the lineages of the eastern coast of Brazil is presented in Marceniuk et al. (in press).

\section{Bairdiella goeldi sp. nov.}

(Figure 4a, Tables 4, 5)

zoobank.org:act:561CDE1C-E23D-411E-BBCE-81E3B862BEB0

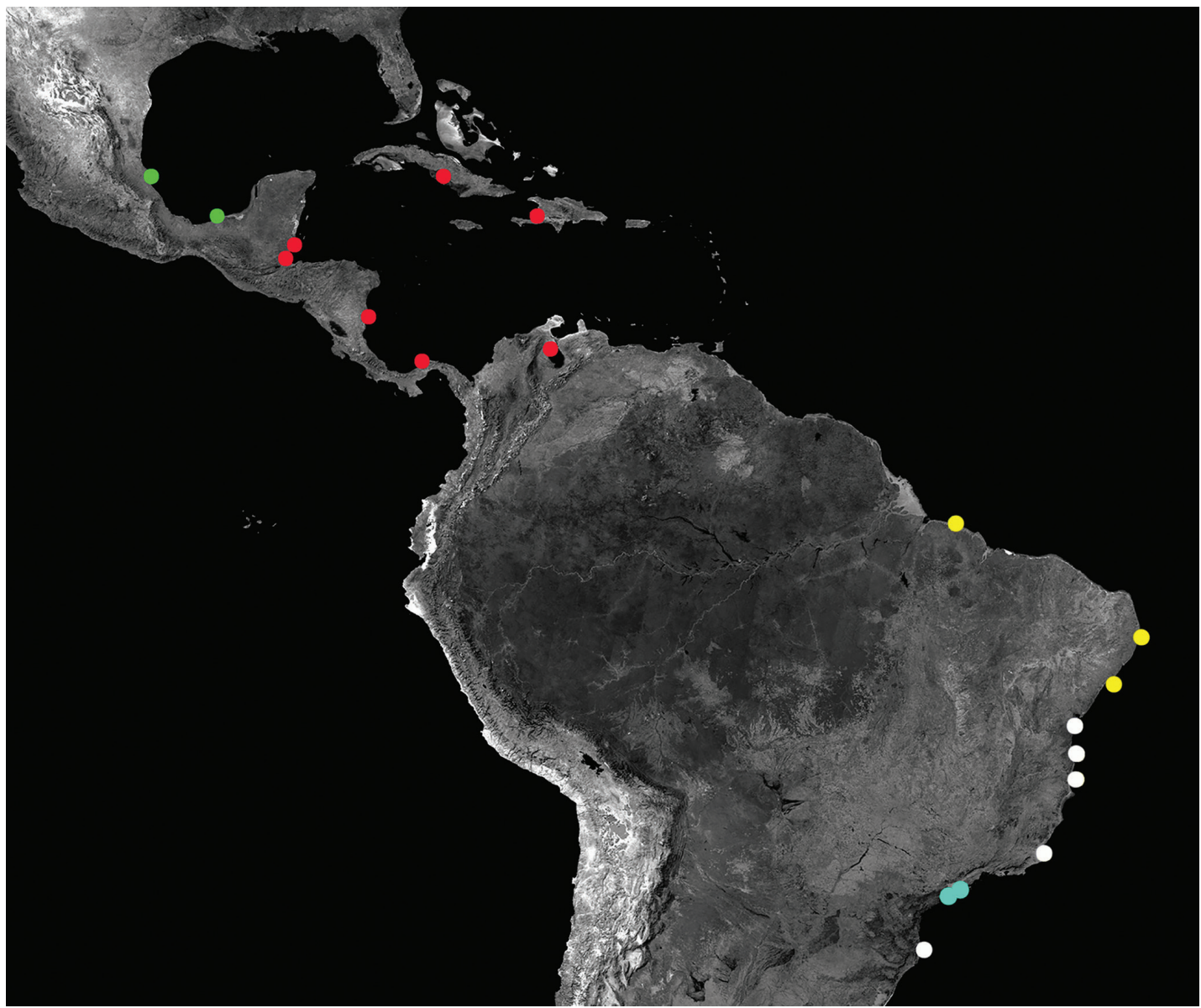

Fig. 3. The Atlantic coast of North, Central, and South America showing the geographic distribution of Bairdiella goeldi sp. nov. (yellow = molecular north-northeastern lineage, light blue = molecular southeastern lineage, white = no molecular data), $B$. ronchus (red), and B. veraecrucis (green). Some symbols represent more than one locality or a large number of specimens. 


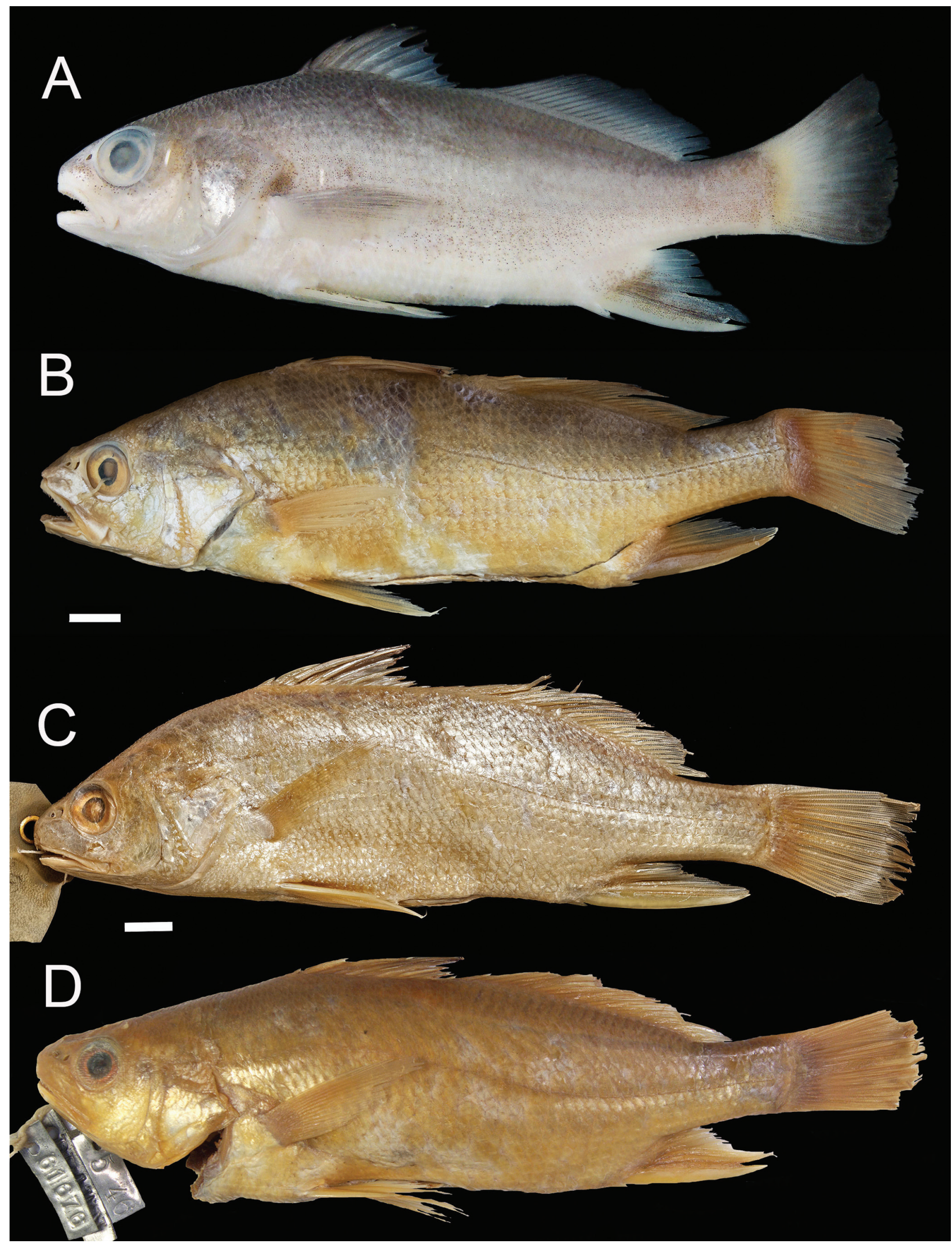

Fig. 4. A. Holotype of Bairdiella goeldi sp. nov. from Bragança, Pará, Brazil, 190 mm SL, MPEG 33641. B. Syntype of Corvina ronchus from the Dominican Republic, MNHN 0095. C. Syntype of Sciaena bedoti from Cuba, BMNH 1905.3.18.2. D. Holotype of Bairdiella veraecrucis from Veracruz, Mexico, USNM 61676. 
Bairdiella ronchus (not of Cuvier, 1830).- Jordan, Evermann, 1898: 1436 (in part; fishes of North and Middle America; West Indies and along coast of Brazil).- Miranda Ribeiro, 1915: 432 (Fauna Brasiliense, listed; description, distribution).- Vazzoler, 1970: 14 (fish fauna, Santos Bay, São Paulo, Brazil, listed; identification key; description).- Roux, 1973: 138 (Calypso expeditions; coast of South America; listed).- Chao 1978:39 (in part).- Figueiredo, Menezes, 1980: 59, fig. 98 (marine fishes from southeastern Brazil; description, distribution).- Camargo, Isaac 2001:142 (estuarine fishes from Pará, Brazil).- Casatti, Menezes, 2003: 86 (catalog of marine fish species of Brazil; listed).- Chao, 2003:1602 (in part).

Holotype. MPEG 33641, 1, 154.0 mm SL, Brazil, Pará, Bragança, Furo da Ostra, 13 Feb 2014, Alexandre Pires Marceniuk, using gillnets (the same method used for all other type-specimens).

Paratypes. MPEG 32860, 1, 146.0 mm SL, Brazil, Pará, Bragança, Furo da Ostra; MPEG 33653, 1, 164.0 mm SL, Brazil, Pará, Bragança, Furo da Ostra, 17 Jul 2014; MPEG 33654, 4, 158.0-176.0 mm SL, Brazil, Pará, Bragança, Furo da Ostra, 10 Jul 2014; MPEG 34510, 2, 119.0-127.0 mm SL, Brazil, Pará, Bragança, Furo da Ostra, 09 Jan 2016; MPEG 33627, 2, 114.0-116.0 mm SL, Brazil, Pará, Bragança, Furo da Ostra, 21 Jan 2014; MPEG 33628, 1, 117.0 mm SL, Brazil, Pará, Bragança, Furo da Ostra, 18 Jan 2014; MPEG 33615, 1, 116.0 mm SL, Brazil, Pará, Bragança, Furo da Ostra, 17 Aug 2013; AZUSC 4926, 9, 129.0-161.0 mm SL, Brazil, Pará, Bragança, Furo da Ostra; LBP 19376, 4, 139.0-178.0 mm SL (tissue 76171-76174), Brazil, Pará, Bragança, Furo da Ostra, 2014.

Non-type specimens, MZUSP 68517, 1, $111.0 \mathrm{~mm}$ SL, Brazil, Maranhão, São Luís, rio Curuca; LBP 22205, 1 (tissue 84692), Brazil, Paraíba, Barra de Mamanguape; USNM 104265, 1, 111.0 mm SL, Brazil, Pernambuco, Recife; MPEG 1660, 1 (tissue 84204), Brazil, Alagoas, Barra de Santo Antonio; USNM 43365, 1, 144.0 mm SL, Brazil, Bahia; MZUSP 68501, 3, 170.0-198.0 mm SL, Brazil, Bahia, rio Paraguaçu, Cachoeira; MZUSP 82209, 3, 98.0-157.0 mm SL, Brazil, Bahia, between Valença and Itacaré; MZUSP 98958, 1, 143.0 mm SL, Brazil, Bahia, Comandatuba island; AZUSC 3957, 2, 162.0-174.0 mm SL, Brazil, São Paulo, rio do Meio, Guarujá, São Paulo; MZUSP 112337, 5, 90.0-170.0 mm SL, Bra- zil, São Paulo, rio Cubatão; MZUSP 2499, 1, 157.0 mm SL, Brazil, São Paulo, Santos; AZUSC 4222, 3, 153.0-186.0 mm SL, Brazil, São Paulo, Santos, estuary channel; AZUSC 363, 2, 154.0-169.0 mm SL, Brazil, São Paulo, Santos, rio Diana; AZUSC 3260, 3, 136.0-171.0 mm SL, Brazil, São Paulo, Santos, Caneu; AZUSC 2860, 2, 108.0-152.0 mm SL, Brazil, São Paulo, São Vicente, rio Mariana; AZUSC 3103, 2, 100.0152.0 mm SL, Brazil, São Paulo, São Vicente, Mar Pequeno bridge; MZUSP 108213, 1, 127.0 mm SL, Brazil, São Paulo, Praia Grande; MZUSP 108229, 1, 129.0 mm SL, Brazil, São Paulo, Praia Grande; MZUSP 68514, 1, 131.0 mm SL, Brazil, São Paulo, Itanhaém; MZUSP 58712, 1, 144.0 mm SL, Brazil, São Paulo, Peruíbe, rio Guaraú; AZUSC 3712, 2,150.0197.0 mm SL, Brazil, São Paulo, Cananeia, estuary; MZUSP 46737, 1, 124.0 mm SL, Brazil, Santa Catarina, Porto Belo.

Diagnosis. Bairdiella goeldi sp. nov. can be differentiated from $B$. armata, which occurs between the Gulf of California and Colombia (EP), by having 50-55 scales with pores on the lateral line, rarely 48 or 49 (vs. 46-49, Tab. 5); from B. chrysoura, which is found between Cape Cod (US) and the western Gulf of Mexico, by the presence of five pores on the chin (vs. six), and a very robust second anal fin spine, as long as the first anal-fin ray ( $v s$. thin second anal fin spine, shorter than first anal-fin ray, Fig. 4a); from B. ensifera, which is found between Mexico and Peru (EP), by having wavy stripes or dark spots on the body ( $v s$. body silvery without stripes or spots, Fig. 4a); from B. icistia, which is found between the Gulf of California and Guatemala (EP), by the presence of 21-24 rays in the dorsal fin (vs. 25-29, Tab. 5) and the lack of a dark spot at the base of the pectoral fins ( $v s$. with dark spot at the base of the pectoral fins, Fig. 4a); from $B$. ronchus, which is found in the Greater Caribbean Central Province, and B. veraecrucis, which is found between Florida (US) and the northern Gulf of Mexico, by having an orbital diameter greater than $8 \%$ SL (vs. less than $8 \%$ SL, Fig. 5a), and the length of the caudal peduncle 1.6-2.3 times the orbital diameter, rarely more than 2.3 (vs. 2.4-3.8, Fig. $5 b)$. Bairdiella goeldi $\mathrm{sp}$. nov. is further distinguished from $B$. veraecrucis, which is found between Florida (US) and the northern Gulf of Mexico, by having a larger head and shorter dorsal fin (Tab. 4), with dorsal fin length 1.7-2.4 times in the head length (vs. 1.2-1.5, Fig. 5c), and dorsal fin length 1.82.6 times in the head depth (vs. 1.2-1.5, Fig. 5d).

Tab. 4. Genetic distances and standard error between groups based on the nucleotide substitution Kimura's two parameter model (1980). In the main diagonal, the genetic distance and standard error within groups. $\mathrm{n} / \mathrm{c}=\mathrm{not}$ computed.

\begin{tabular}{lcccccc}
\hline & 1 & 2 & 3 & 4 & 5 & 5 \\
\hline 1 Bairdiella chrysoura & $\mathbf{0 . 0 0 1} \pm \mathbf{0 . 0 0 1}$ & & & & & \\
2 Bairdiella goeldi sp. nov. & $0.180 \pm 0.018$ & $\mathbf{0 . 0 0 5} \pm \mathbf{0 . 0 0 2}$ & & & & \\
3 Bairdiella ronchus & $0.183 \pm 0.019$ & $0.018 \pm 0.005$ & $\mathbf{n} / \mathbf{c}$ & & & \\
4 Bairdiella veraecrucis & $0.185 \pm 0.019$ & $0.039 \pm 0.008$ & 0.0300 .007 & $\mathbf{n} / \mathbf{c}$ & & \\
5 Corvula macrops & $0.165 \pm 0.017$ & $0.164 \pm 0.017$ & 0.1620 .017 & $0.171 \pm 0.019$ & $\mathbf{0 . 0 0 5} \pm \mathbf{0 . 0 0 3}$ & \\
6 Corvula sanctaeluciae & $0.177 \pm 0.018$ & $0.191 \pm 0.020$ & 0.1830 .020 & $0.194 \pm 0.021$ & $0.140 \pm 0.016$ & $\mathbf{0 . 0 0 4} \pm \mathbf{0 . 0 0 2}$ \\
7 Odontoscion dentex & $0.180 \pm 0.018$ & $0.178 \pm 0.018$ & 0.1740 .018 & $0.179 \pm 0.019$ & $0.150 \pm 0.017$ & $0.180 \pm 0.019$ \\
\hline
\end{tabular}




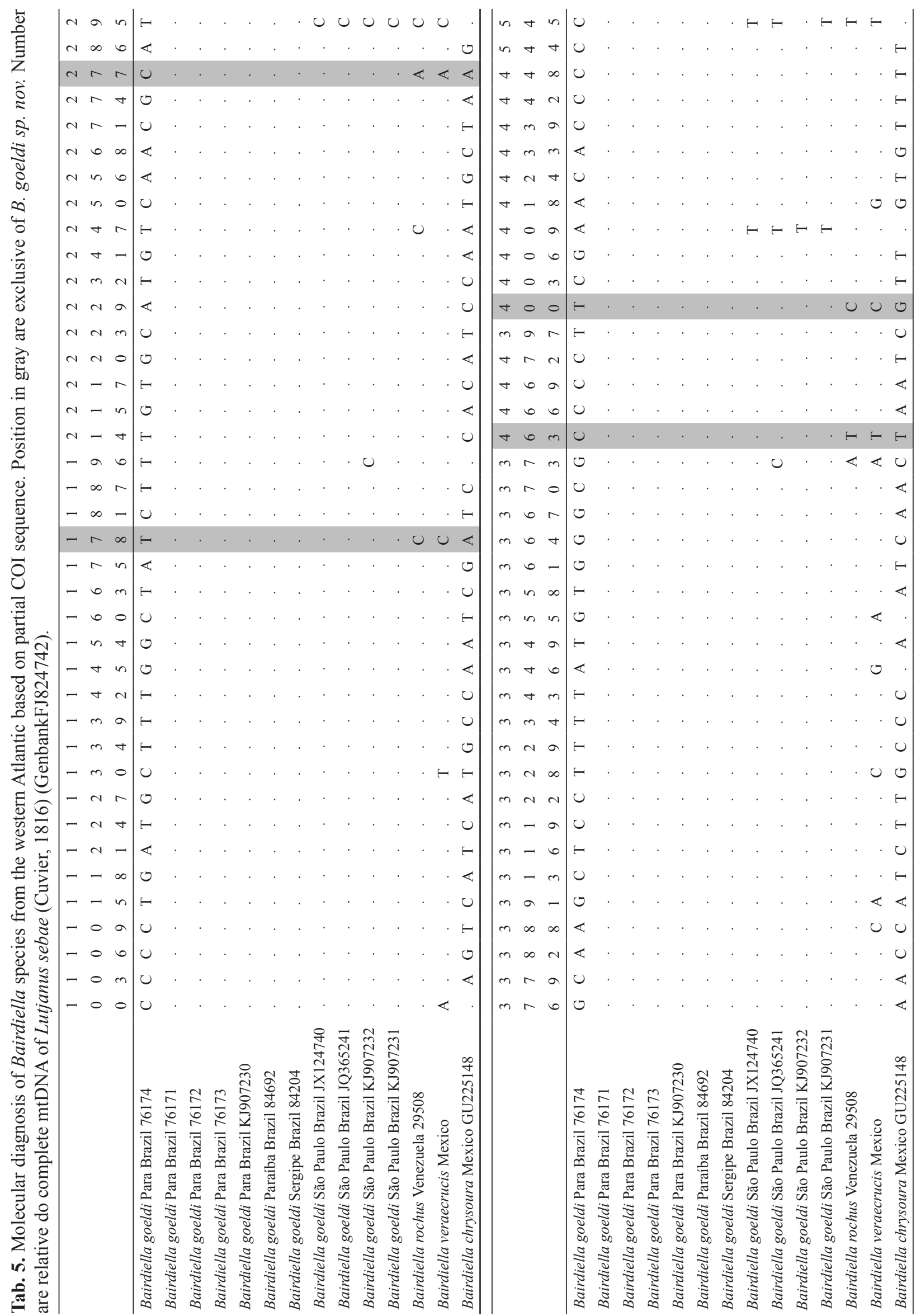




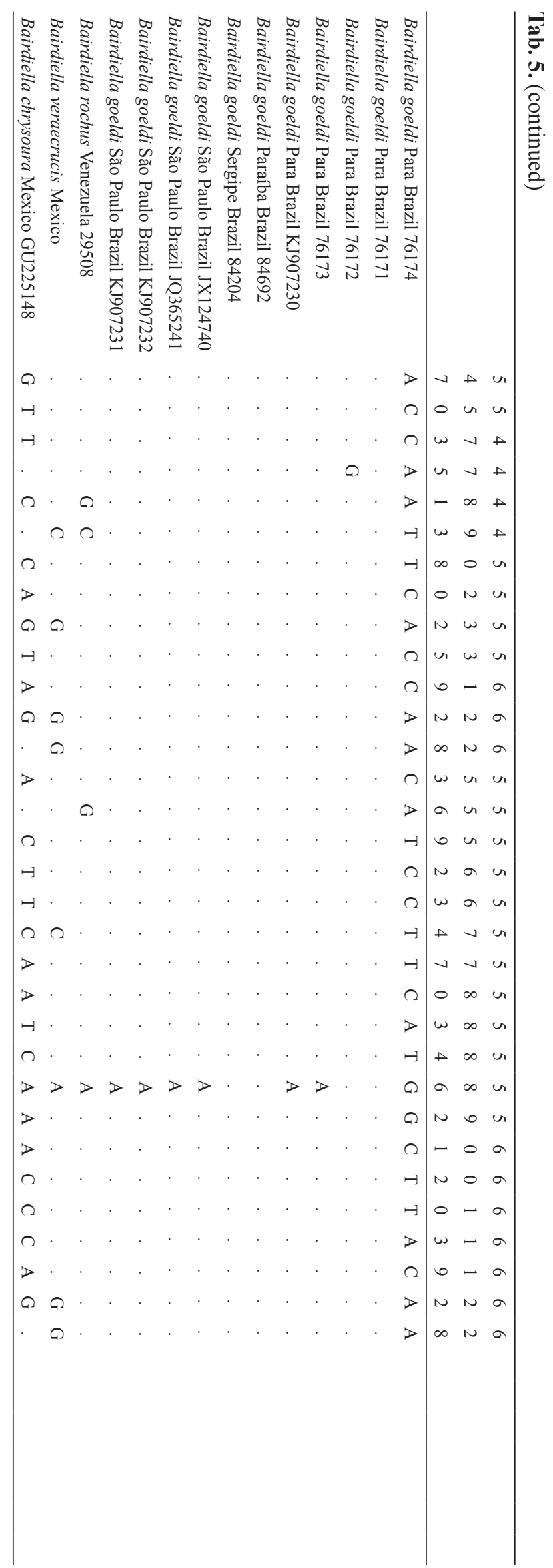



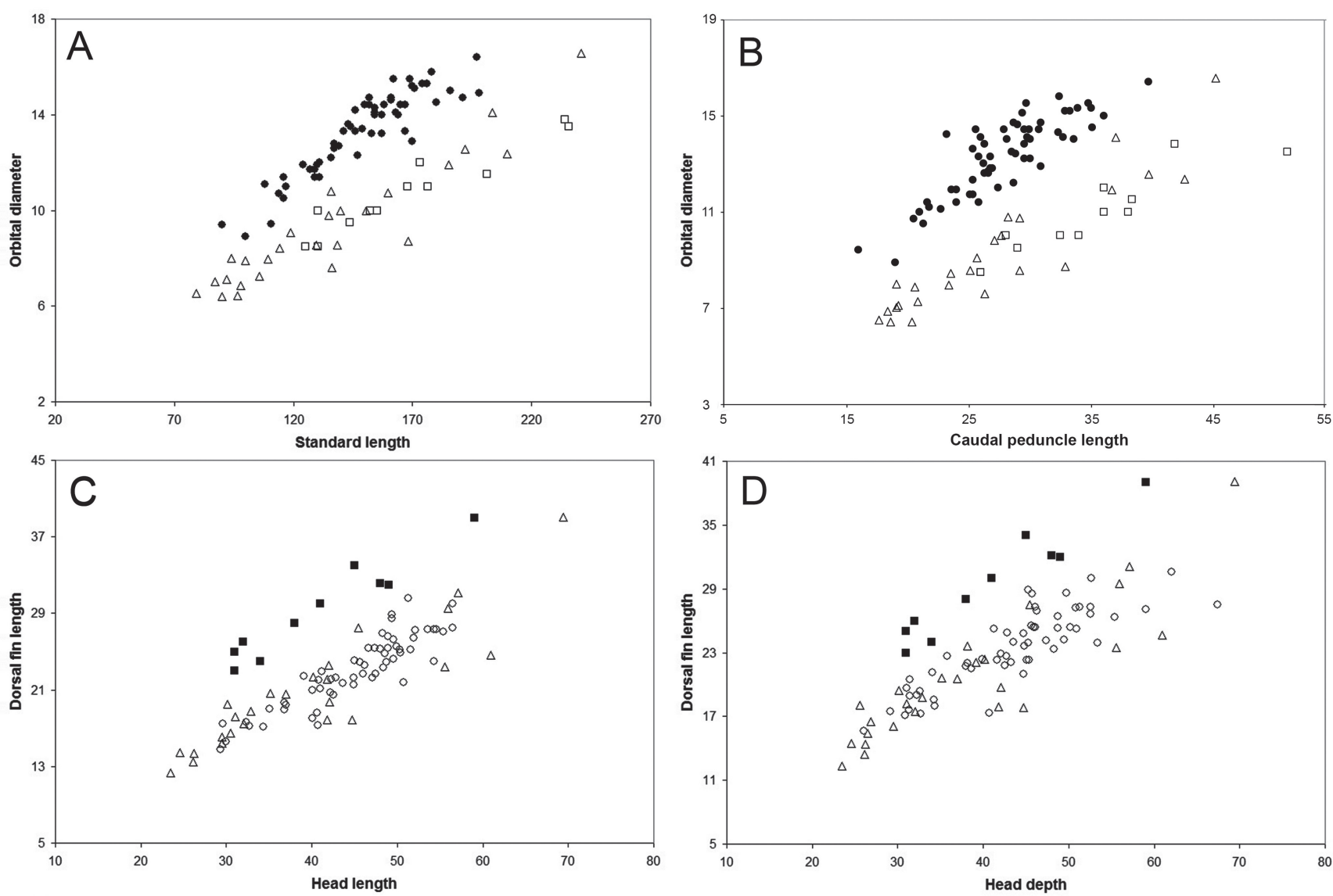

Fig. 5. Plots of the standard length versus orbital diameter (A), head length versus dorsal fin length (B), and head depth versus dorsal fin length (C) in Bairdiella goeldi sp. nov. (circles), B. ronchus (triangles), and B. veraecrucis (squares).

Molecular diagnosis. The haplotypes of B. goeldi sp. nov. differed by four bases from those of all the other Atlantic species analyzed, by nine bases from B. ronchus, 19 bases from B. veraecrucis, and 97 bases from B. chrysoura (Tab. 3 ), with genetic distances of $0.018 \pm 0.005$ from $B$. ronchus, $0.039 \pm 0.008$ from $B$. veraecrucis, and $0.180 \pm 0.018$ from $B$. chrysoura (Tab. 2). A total of 11 haplotypes were identified in the 14 specimens of $B$. goeldi sp. nov. sequenced, which formed two distinct lineages: (1) the specimens from the Brazilian states of Pará, Paraiba, and Sergipe, and (2) the specimens from São Paulo state (Fig. 2). These lineages are differentiated by a genetic distance of $0.007 \pm 0.003$ and two base pairs, at positions 295 and 409 (Tabs. 2, 3).

Description: Morphometric and meristic data were employed in Tabs. 4, 5. D. X+I.21-24; A.II.8-10; P. 15-18; gill rakers 22-26; pored lateral line scales to caudal fin base 4855; scale rows above lateral line 8-10, below 9-12. Body moderately long and compressed, maximum depth at dorsal fin origin. Dorsal profile straight, ascending until dorsal fin origin, posteriorly convex until caudal peduncle, especially on larger specimens. Ventral profile flattened from pelvic fin to anal fin origin. Head relatively long and high. Snout blunt in lateral view, dorsal profile naked. Mouth nearly terminal, oblique in lateral view; posterior tip of premaxilla reaching vertical through middle of orbit. Teeth conical, premaxilla with 3-5 rows, external row with 15-20 enlarged teeth, dentary with 2-4 rows. Orbit lateral; eye round, very large, orbital diameter greater than snout length. Interorbital space smaller than orbital diameter, slightly convex, covered with ctenoid scales (cycloid anteriorly). Nostrils visible with naked eye, anterior nostril oval, posterior nostril larger and teardrop like, close to anterior eye margin, over or nearly above horizontal line through middle of orbit. Lateral sensory canal on head visible on infraorbital, dentary and preopercle; five ventral pores on dentary tip, one central smaller, oval, and two pores on each side; small circular pore on anterior preopercle border. Preopercle margin serrated, with about 10-15 spines, two or three at angle largest. Opercle tip angled, slightly posterior to vertical line that passes through pectoral-fin base. Gill rakers well developed. Scales ctenoid on trunk, belly, pectoral fin base, opercle, preopercle, infraorbital (two ventral most rows) and interorbital region in specimens larger than $150 \mathrm{~mm} \mathrm{SL}$; scales cycloid on infraorbital (anteriorly), preorbital region below nostrils, opercle and interobital, specially in specimens smaller than $150 \mathrm{~mm}$ SL. Lateral line simple, slightly arched below first dorsal fin to middle of second dorsal fin, straight elsewhere. First dorsal fin without scales, membranes of second dorsal fin and anal fin with one or two series of 5-7 small cycloid 
scales. Base of pectoral fin covered by scales, cycloid scales to proximal third of fin present in largest specimens. Caudal fin base covered with cluster of small cycloid scales, rows of cycloid scales on caudal-fin rays, nearly three quarters of their length. Spinous dorsal fin short, first spine shortest, spines III-V longest; small notch between first and second dorsal fin. Origin of second dorsal fin slightly in front of vertical through pectoral fin tip, with second dorsal soft rays slightly shorter than longest first dorsal spines. Pectoral fin falcate, relatively long, length approximately equal to second anal fin spine length. Pelvic fin origin behind vertical though pectoral fin base. Anal fin emarginated, second anal-fin spine very stout and longer than remaining spines. \pm Caudal peduncle depth about equal to eye length, 9.6-12.2 $\%$ SL; length $16.2-21.4 \% \mathrm{SL}$; caudal fin truncated to slightly rhomboidal, central rays longest.

Color in alcohol. Grayish above lateral line, silvery below lateral line, dark stripes slightly more evident in the fresh specimens, oblique above lateral line, but more or less parallel below lateral line. Dorsal, anal, and caudal fins blackish, basal portion of the anal and caudal fins yellowish. Pectoral and pelvic fins yellowish, but with some dark pigmentation.

Distribution and habitat. Widely distributed on the Atlantic coast of Brazil, from at least the equatorial northern state of Pará to Santa Catarina. The southern limit of occurrence is apparently determined by the absence of mangrove forests in estuaries. The species is relatively rare in the northeastern coast of Brazil, but is abundant in estuarine waters on sandy or muddy bottoms on the northern and southeastern coasts of Brazil (Fig. 3).

Ecological notes. This species has no commercial importance in Brazil (as Bairdiella ronchus in Itagaki et al., 2007). It is incidentally caught as bycatch in bottom trawls, gillnets, and seines, as well as by cast nets in mangrove swamps.

Etymology. Bairdiella goeldi sp. nov. is named in honor of the Goeldi Museum (Museu Paraense Emílio Goeldi) in Belém, Pará (Brazil), that supported taxonomic research on the marine and estuarine fish of Brazil (APM), and the expeditions for the collection of specimens on the northern and northeastern coasts of Brazil.

Conservation status. Bairdiella goeldi is frequent and abundant. No specific threats were detected, and the species can be categorized as Least Concern (LC) according to IUCN criteria (IUCN, 2016).

Remarks. Günther (1860) recorded Corvina ronchus (= Bairdiella ronchus) from the Brazilian coast based on a single specimen from Bahia state, while Jordan, Eigenmann (1889) identified specimens from Rio de Janeiro state as Bairdiella ronchus. This classification was followed by Miranda-Ribeiro (1915), Vazzoler (1970), Menezes, Figuei- redo (1980), and Menezes et al. (2003). Meek, Hildebrand (1925) found individual variation among Bairdiella populations, although they decided that these differences were not sufficient to justify the recognition of two distinct species of the genus in the western Atlantic.

\section{Bairdiella ronchus (Cuvier, 1830)}

\section{(Fig. 4b, c, Tables 4, 5)}

Corvina ronchus Cuvier, 1830:107 (Lake Maracaibo, Venezuela; Dominican Republic; Cuba; Suriname MNHN 0095 (1) Dominican Republic, MNHN 5345 (2) Suriname, MNHN 7634 (1, dry) Maracaibo, MNHN 7637 (1), MNHN A-5543 (1) Martinique.-Günther, 1860: 299 (Catalogue of the Fishes in the British Museum).

Sciaena bedoti Regan, 1905:391, Pl. 6 (fig. 1) (Cuba. Syntypes: BMNH 1905.3.18.2 [ex MHNG] (1), MHNG 678.01 (1)).

Bairdiella ronchus Poey, 1868: 324 (fishes of Cuba; synopsis).Jordan, Eigenmann, 1889: 388 (review of sciaenids from America and Europe).- Jordan, Evermann, 1898: 1436 (in part; description and synonymy).- Meek, Hildebrand, 1925: 634635 (fishes of Panama; description; in part).- Mago-Leccia, 1965: 309 (rio Unare, Venezuela; listed).- Chao, 1978:39 (in part, redescription).- Cervigón, 1992: 398 (in part, fishes of Venezuela; listed).- Cervigón, 1993:242 (in part, fishes of Venezuela; listed).- Greenfield, Thomerson, 1997:182 (fishes of Belize; listed).- González Bencomo et al., 1997:159 (fishes of Maracaibo, Venezuela; listed).- Aguilera, 1998:50 (fishes of Occidental Venezuela; listed).- Marín, 2000:75 (fishes of Unare Lagoon, Venezuela; short description).- Smith et al., 2003:37 (fishes of Pelican Cays, Belize; listed).- Matamoros et al., 2009:19 (fishes of Honduras; listed).- Angulo et al., 2013:1002 (checklist of fishes from Costa Rica).

Diagnosis. Bairdiella ronchus is distinct from B. armata (EP), which occurs between the Gulf of California and Colombia (EP), by the presence of 50-53 scales with pores on the lateral line, rarely 49 (vs. 46-49, Tab. 5a); from B. chrysoura (WA), which is found between Cape Cod (US) and the western Gulf of Mexico, by the presence of five pores on the chin (vs. six), and a very robust second anal-fin spine, as long as the first anal-fin ray ( $v s$. thin second anal-fin spine, shorter than first anal-fin ray, Fig. 4b,c); from B. goeldi sp. nov., which is found on the Brazilian coast, by having an orbital diameter less than $8 \%$ SL (vs. more than $8 \%$ SL, Fig. $5 \mathrm{a}$ ), and orbital diameter 2.4-3.8 times the caudal peduncle length ( $v$ s. 1.6-2.3, rarely more than 2.3, Fig. 5 b); from $B$. ensifera (EP), which is found between Mexico and Peru (EP), by having wavy stripes or dark spots on the body ( $v s$. body silvery without stripes or spots, Fig. $4 \mathrm{~b}, \mathrm{c}$ ); from $B$. icistia (EP), which is found between the Gulf of California and Guatemala (EP), by the presence of 22-24 rays in the dorsal fin (vs. 25-29, Tab. 5d), 22-24 gill rakers on the first branchial arch, rarely more than 24 (vs. 25-27, Tab. 5f), and the lack of a dark spot at the base of the pectoral fins (vs. with 
dark spot at the base of the pectoral fins, Fig. 4b,c); from $B$. veraecrucis (WA), which occurs between Florida (US) and the northern Gulf of Mexico, by having a relatively larger head and dorsal fin relatively shorter (Tab. 4), with dorsal fin length 1.6-2.5 times in the head length (vs. 1.2-1.5, Fig. $5 \mathrm{c}$ ), and dorsal fin length 1.7-2.7 times in the head depth (vs. 1.2-1.5, Fig. 5d).

Molecular diagnosis. The haplotypes of B. ronchus differed by three bases from of all the other Atlantic species analyzed, by nine bases from $B$. goeld $i$ sp. nov., by 17 bases from B. veraecrucis, and by 97 bases from B. chrysoura (Tab. 3), with genetic distances of $0.018 \pm 0.005$ from $B$. goeldi sp. nov., $0.030 \pm 0.007$ from $B$. veraecrucis, and $0.183 \pm 0.019$ from $B$. chrysoura (Tab. 2).

Description. Morphometric and meristic data are presented in Tabs. 4, 5. D. X+I. 22-24; A.II.8; P. 16-18; gill rakers 22-26; pored lateral line scales to caudal fin base $49-53 \pm$; scale rows above lateral line 8-9 (rarely 10), below 9-11. Body moderately long and compressed, maximum depth at origin of dorsal fin. Dorsal profile straight, ascending until dorsal fin origin, posteriorly convex until caudal peduncle, especially in larger specimens. Ventral profile flattened from pelvic fin to anal fin origin. Head relatively long, high. Snout blunt in lateral view, dorsal profile naked. Mouth terminal, barely inclined; posteriorrmost tip of premaxillary bone passing vertical through middle of orbit. Teeth conical, premaxilla with three or four rows, external row with enlarged teeth; dentary with one row. Orbit lateral, eyes round, moderately large, orbital diameter approximately equal to snout length. Interorbital space larger than orbital diameter, slightly convex, covered with ctenoid scales (cycloid anteriorly). Nostrils visible with naked eye, anterior nostril oval, posterior nostril larger and teardrop like, close to anterior eye margin, over or nearly above horizontal line through middle of orbit. Lateral sensory canals on head visible on infraorbital, dentary and preopercle; five ventral pores on dentary, one central, triangular and subequal in size, and two pores on each side. Preopercle margin serrated, with about 12-15 spines, two or three at angle largest. Opercle tip angled, slightly anterior to vertical through pectoral fin base. Gill rakers well developed. Scales ctenoid on trunk, belly, pectoral fin base, opercle, preopercle, infraorbital (ventral most two rows) and interorbital region, especially in specimens larger than $150 \mathrm{~mm}$ SL; cycloid on infraorbital (anteriorly), preorbital region below nostrils, opercle and interobital in specimens smaller than $150 \mathrm{~mm}$ SL. Lateral line simple, arched above the pectoral fin to middle of second dorsal fin, straight elsewhere. First dorsal fin without scales, membranes of second dorsal fin and anal fin with one or two rows of 5-7 small cycloid scales. Base of pectoral fin covered with cycloid scales, extending to proximal third in largest specimens. Caudal fin base covered with a cluster of small cycloid scales, rows of cycloid scales on caudal-fin rays, nearly three quarters of their length. Spinous dorsal fin short, first spine shortest, spines IV-V longest, with small notch between first and second dorsal fin. Origin of second dorsal fin posterior to vertical through pectoral fin tip, with second dorsal soft rays shorter than the longest first dorsal-fin spines. Pectoral fin falcate and relatively short, its length approximately equal to the second anal spine length. Pelvic fin origin behind vertical though pectoral fin base. Anal fin emarginated, second anal-fin spine very stout and longer than remaining spines. Caudal peduncle depth slightly larger than eye diameter, 10.4-11.9\% SL, length 18.2-22.2\% SL; caudal fin truncated to slightly rhomboidal, central rays longest.

Color in alcohol. Dusky blue in the dorsal portion above lateral line and on the top of the head, silver below lateral line, with bands of pigments on the flanks, oblique at the top and more or less parallel below lateral line. The dorsal, anal and caudal fins are dusky, pelvic fins are yellowish, and the pectoral fins are yellowish only at their bases.

Distribution and habitat. Greater Caribbean Central Province, Central America, West Indies, Bermuda, and Venezuela (Fig. 3).

Remarks. In a comprehensive review of the genus Bairdiella, Chao (1978), following previous authors, synonymized Bairdiella armata Gill, 1863, Corvina subaequalis Poey, 1875, Corvina fulgens Vaillant \& Bocourt, 1883, Bairdiella veraecrucis, and Sciaena (Bairdiella) bedoti Regan, 1905 without examining the type specimens or listing the material examined. As result, B. ronchus was considered to be widely distributed in the western Atlantic, from North Carolina to southern Brazil (Cervigón, 1992; McEachran, Fechhelm, 2003, see comments on B. goeldi sp. nov., above). Here, Bairdiella ronchus is redefined based on morphological (Fig. 1) and molecular evidence (Fig. 2, Tabs. 2, 3), and its distribution is restricted to the Greater Caribbean Central Province, between Cuba and Venezuela. As Venezuela is one of the type localities of the species, MHNH 7634, collected from Lake Maracaibo, Venezuela, is recognized as the lectotype of the present designation.

The recognition of Corvina fulgens Vaillant \& Bocourt, 1883 as a junior synonym of $B$. ronchus by Chao (1978) is erroneous, given that Vaillant, Bocourt (1883) described $C$. fulgens based on two specimens collected at La Union, El Salvador, in the eastern Pacific, during a scientific expedition to Mexico and Central America. Furthermore, the original description of $C$. fulgens includes an error in the scale count (115/8/5 scales above, on and below the lateral line, respectively; Vaillant, Bocourt, 1883: p. 164). The authors provide the correct count $(11 / 58 / 15)$ when subsequently comparing the new species to Corvina macrops Steindachner, 1876, commenting that "This species appears to be approaching the Corvina macrops, [...] But the latter fish is higher [...] Of the scales, in particular for the transverse line, also differs, 
$7 / 60 / 11$ instead of $11 / 58 / 15$ " (p. 165). Further examination of the syntypes of $C$. fulgens (MNHH A-0975) revealed that they have 23 soft rays in the second dorsal fin, and less than 55 scales in the lateral line to the caudal fin base. $C$. fulgens is therefore regarded as a junior synonym of $B$. armata Gill, 1863.

Corvina subaequalis Poey, 1875 was described from a $245 \mathrm{~mm}$ TL specimen collected in Cuba. The author indicated that this specimen was sent to the Berlin Museum (ZMB), but it was not cataloged and is presumably lost. The holotype of C. subaequalis was not illustrated, and the description of this species is not accurate enough to differentiate it from several western Atlantic sciaenids. Despite those situations, Chao (1978) considered C. subaequalis to be a junior synonym of $B$. ronchus, without providing arguments for that decision. Some of the information in Poey's description is discrepant from the characteristics observed in specimens of $B$. ronchus, such as the presence of fine denticulations in the preopercle (p. 59) vs. moderately largely serrated in all specimens of Bairdiella we examined, and the presence of 25 soft rays in the dorsal fin ( $v s .21-24$ soft rays), which may be attributable to individual variation, ontogeny or differences in counting the last two conjoined dorsal and anal fin rays as one element or not. However, as images of the holotype of $C$. subaequalis are not available and the type specimen is probably lost, the exact affiliation of this taxon with B. ronchus cannot be ascertained. Therefore, C. subaequalis should be regarded as nomen dubium.

Material examined. LBP 6080, 2, 135-136 mm SL, Venezuela, Ilsa de Margarita, mouth of Rio Nova Esparta, Isla de Margarita; LBP 6436, 2, 92-94 mm SL, Venezuela, Isla de Margarita, mouth of Rio Nova Esparta; USNM 4704, 1, 106 mm SL, Cuba; USNM 32090, 1, 209 mm SL, Cuba; USNM 44185, 1, 119 mm SL, Nicaragua, Greytown; USNM 81164, 1, 114 mm SL, Panama, Mindi Cut; USNM 80710, 1, 185 mm SL, Panama, Mindi Reef; USNM 80711, 1, 130 mm SL, Panama, Mindi Cut; USNM 81165, 1, 109 mm SL, Panama, Mindi Cut; USNM 80708, 1, 151 mm SL, Panama, Colon market; USNM 81166, 1, 79 mm SL, Panama, Portobelo; USNM 81168, 2, 87-97 mm SL, Panama, Cristobal; USNM 114303, 1, 203 mm SL, Guatemala, Laguna Grande; USNM 121746, 2, 90-98 mm SL, Venezuela, Cano de Agua; USNM 133714, 2, 192-241 mm SL, Haiti; USNM 178227, 2, 138-168 mm SL, Haiti; USNM 300471 , 3, 136-160 mm SL, Belize, east of Dangriga; USNM 343624, 1, $100 \mathrm{~mm}$ SL, Cuba, Cayo Mendoza, Cuba.

\section{Bairdiella veraecrucis Jordan \& Dickerson, 1908}

\section{(Fig. 4d, Tables 4, 5)}

Sciaena ronchus Jordan, 1886:44 (United States; listed).

Bairdiella veraecrucis Jordan, Dickerson, 1908:16, fig. 1 (Veracruz, Mexico. Holotype: USNM 61676. Paratypes: CAS-SU 20654).

Bairdiella ronchus (not of Cuvier, 1830).- Jordan, Evermann, 1898: 1436 (in part; description; synonymy).- Castro-Aguirre et al., 1999:383 (fishes of Mexico; listed).- Nelson et al., 2004:146 (common names of fishes from the United States; listed).- McEachran, Fechhelm 2005:416 (fishes of the Gulf of Mexico; short description).- Page et al., 2013:151 (common and scientific names of fishes from the United States; listed).

Diagnosis. Bairdiella veraecruciscan be differentiated from B. armata (EP), which occurs between the Gulf of California and Colombia (EP), by having 50-52 pored scales on the lateral line, rarely 49 (vs. 46-49, Tab. 5); from B. chrysou$r a$, which is found between Cape Cod (US) and the western Gulf of Mexico, by the presence of five pores on the chin (vs. six) and by a very robust second anal-fin spine, as long as the first anal-fin ray ( $v s$. thin second anal-fin spine, shorter than first anal-fin ray, Fig. 4d); from B. goeldi sp. nov., which is found on the Brazilian coast, by having an orbital diameter less than $8 \%$ SL ( vs. more than $8 \%$ SL, Fig. 5a), caudal peduncle length 2.8-3.7 times the orbital diameter (vs. 1.6-2.3, rarely more than 2.3 , Fig. 5 b), and a relatively smaller head and longer dorsal fin (Tab. 4), with dorsal fin length 1.21.5 times the head length (vs. 1.7-2.4, Fig. 5c), dorsal fin length and 1.2-1.5 times head depth (vs. 1.8-2.6, Fig. 5d); from $B$. ensifera (EP), which is found between Mexico and Peru (EP), by having wavy stripes or spots on the flanks (vs. body silvery without stripes or spots, Fig. 4d); from B. icistia (EP), which is found between the Gulf of California and Guatemala (EP), by having 22-24 rays on the dorsal fin (vs. 25-29, Tab. 5d), 21-24 gill rakers on the first brachial arch (vs. 25-27, Tab. 4), and no dark spot at the base of pectoral fins (vs. with dark spot at base of pectoral fins); from B. ronchus (WA), which is found in the Greater Caribbean Central Province, by its relatively smaller head and longer dorsal fin (Tab. 4), with dorsal fin length 1.2-1.5 times the head length (vs. 1.6-2.5, Fig. 5c), and dorsal fin length 1.2-1.5 times the head depth (vs. 1.7-2.7, Fig. 5d).

Molecular diagnosis. The haplotypes of $B$. veraecrucis differed by four bases from those of all the other Atlantic species analyzed, by nine bases from $B$. goeldi sp. nov., by 19 bases from $B$. ronchus, and by 97 bases from $B$. chrysoura (Tab. 3), with genetic distances of $0.039 \pm 0.008$ from $B$. goeldi sp. nov., $0.030 \pm 0.007$ from $B$. ronchus, and $0.185 \pm 0.019$ from B. chrysoura (Tab. 2).

Description. Morphometric and meristic data are presented in Tabs. 4, 5. D. X+I.22-24; A.II.8; P. 16-18; gill rakers 21-24; pored lateral line scales 49-52; scale rows above lateral line 8-9, below 10-11. Body moderately long and compressed, maximum depth at origin of dorsal fin. Dorsal profile nearly straight, ascending until first dorsal fin origin, posteriorly slightly convex until caudal peduncle. Ventral profile straight from pelvic fin to anal fin. Head relatively short, low. Snout blunt in lateral view, dorsal profile naked. Mouth nearly terminal, oblique in lateral view; posterior tip of premaxilla reaching vertical through anterior margin of orbit. Teeth conical, premaxilla with two rows, external row with about 40 larger teeth; dentary with two rows, external row with about 35 larger teeth. Orbit lateral; eye round and 
relatively small, orbital diameter smaller than snout length. Interorbital space slightly convex, covered with cycloid scales. Nostrils visible with naked eye, anterior nostril oval, posterior nostril larger and teardrop like, close to anterior eye margin, over or nearly above horizontal line through middle of orbit. Lateral sensory canals on head visible on infraorbital, dentary and preopercle; five ventral pores on dentary tip, one small, central, oval, and two pores on each side. Preopercle margin serrated, with spines, two or three at angle largest. Opercle tip angled, slightly posterior to vertical through pectoral fin base. Gill rakers well developed. Scales ctenoid on trunk, belly, pectoral fin base and predorsal region, cycloid on opercle, preopercle, infraorbital and interorbital. Lateral line simple, slightly arched below first dorsal fin to middle of second dorsal fin, straight elsewhere. First dorsal fin without scales, second dorsal fin with a row of cycloid scales on proximal half of membranes; membranes of anal fin covered by a row of cycloid scales, except at distal third; pectoral fin base covered by cycloid scales; caudal fin base covered by a cluster of small cycloid scales, rows of cycloid scales on nearly two thirds of caudal fin rays. Spinous dorsal fin short, first spine shortest, third spine longest; small notch between first and second dorsal fin; origin of second dorsal fin slightly in front of vertical through pectoral tip, with second dorsal soft ray about the same length of longest first dorsal spine. Anal fin short, emarginated (more prominently in small specimens), first spine as long and slightly stouter than last spine of first dorsal, second anal spine very stout and longer than remaining spines, width nearly two thirds of pupil diameter. Pectoral fin long, falcate, almost reaching vent; pelvic fin origin behind vertical though pectoral fin base; first pelvic fin longest, reaching vent. \pm Caudal peduncle depth slightly larger than eye diameter, $8.7-10.8 \%$ SL, length $20.0-21.9 \%$ SL; caudal fin slightly rhomboidal, central rays longest.

Coloration. Grayish sections near the dorsal fin, but mostly silver above lateral line, silver below lateral line, tenuous bands of pigment on the flanks, oblique over lateral line and more or less parallel ventral to it. Distal portion of dorsal, anal and caudal fins black, pelvic fin yellowish and base of pectoral fin yellowish.

Distribution and habitat. Northern Greater Caribbean Province, Gulf of Mexico (Fig. 3).

Material examined. CNPE 720, 1, $236 \mathrm{~mm}$ SL, Mexico, Tabasco, Laguna La Redonda; CNPE 2455, 1, 152 mm SL, Mexico, Tamaulipas, Rio Soto la Marina, Vista Hermosa; CNPE 1125, 1, 173 mm SL, Mexico, Veracruz de Ignacio, Laguna de Tamiahua; CNPE 4817, 3, 130-168 mm SL, Mexico, Veracruz de Ignacio, Laguna de Tampamachoco; CNPE 4882, 2, 155-176 mm SL, Mexico, Veracruz de Ignacio, Laguna de Tampamachoco; CNPE 11083, 2, 125-130 mm SL, Mexico, Veracruz de Ignacio, Laguna de Tamiahua; USNM 61676, 1, 201 mm SL, Mexico, Veracruz, Jordan, D. S (Holotype); USNM 62275, 1, 234 mm SL, Mexico, Tampico.

\section{Discussion}

The delimitation of faunal regions is a major challenge for marine biogeography. Widely-distributed groups, such as the Sciaenidae, have attracted a substantial attention from biogeographers, who consider the subfamily Stelliferinae to be an especially appropriate model for the analysis of the genetic connectivity among populations, given that species of the group are widely dispersed in estuarine environments (Barbosa et al., 2014). However, there has been no comprehensive assessment of the evolutionary relationships among species or lineages of Bairdiella. The general lack of intergeneric and interspecific phylogenetic analyses is at least partly due to the limitations of and inconsistencies in species definitions, resulting from a deficiency of data on alpha-taxonomy, and the paucity of museum specimens collected in many geographic areas, especially in South America (Marceniuk et al., 2013).

The revalidation of $B$. veraecrucis supports the recognition of a distinctive fauna in the Gulf of Mexico, as part of the northern Greater Caribbean Province (sensu Robertson, Cramer, 2014). There is, however, no consensus on the definition of the southern limit of the Greater Caribbean Province, which has varied from the Gulf of Paria, in Venezuela, to Suriname (Petuch, 2013), and different points in the coast of Brazil (Robins, 1971). The presence of Bairdiella ronchus in the central Greater Caribbean Province (sensu Robertson, Cramer, 2014) and the occurrence of B. goeldi sp. nov. on the Brazilian coast indicates the existence of distinctive marine-estuarine fish faunas in the Caribbean and Brazil. Whereas a number of studies have demonstrated differences in the fauna of reef-dwelling fishes from the Caribbean and Brazilian coast (Floeter, Gasparini, 2000; Rocha, 2003; Floeter et al., 2008; Bernal, Rocha 2011), biogeographic analyses of the coastal (non-reef) and estuarine fishes of these two regions are scarce (Marceniuk et al., 2016). Until recently, the existing data on the marine and estuarine fish fauna of the western Atlantic indicated that the majority of species found in Brazil also occurred in the Caribbean (Menezes et al., 2003), a situation apparently determined by the absence of any major physical barriers between the two regions. Together with the results of previous studies (Marceniuk et al., 2012, 2016), the findings of the present analysis indicate that this concept needs to be revised, and tested with other taxonomic groups.

In Brazil, recent studies have revealed complex patterns of diversity in marine estuarine species or lineages, with varying estimates of the timing of molecular divergence (Santos, 2016; Silva et al., 2016; Machado et al., 2017) or without molecular differentiation among distinct populations along the coast (Marceniuk et al., 2017). Those results indicate that separate events on different time scales were responsible for distinct evolutionary processes on the Brazilian coast, some of which are still ongoing (Marceniuk et al., 2017; Marceniuk et al., 2019). Robertson, Cramer (2014) concluded that major variations in shelf environments are 
responsible for substantial differences in the faunas of the three provinces of the Greater Caribbean. The same might be valid for the Brazilian coast, given its considerable heterogeneity of environments (da Silva et al., 2016). Further taxonomic reviews of the marine-estuarine fish fauna of the Brazilian coast may also reveal distinct biogeographic patterns on different time scales. This is supported by the two distinctive lineages found in $B$. goeldi sp. nov., underscoring the need for more comprehensive biogeographic studies of the marine and estuarine fish fauna of Brazilian coast (see Pinheiro et al., 2018).

\section{Key to the species of Bairdiella}

1a. Dorsal-fin rays 25-29; gill rakers on first branchial arch 25-27; dark spot at base of pectoral fins B. icistia

(eastern Pacific from Gulf of California to Guatemala)

1b. Dorsal-fin rays 19-24, gill rakers on first branchial arch 22-24; without dark spot at base of pectoral fins............ 2

2a. Six pores on chin; anal-fin rays 8-10, more commonly 9 ; second anal fin spine thin, shorter than first anal-fin ray.. B. chrysoura

(western Atlantic, from Cape Cod to western Gulf of Mexico)

2 b. Five pores on chin; anal-fin rays $8-9$, more commonly 8 ; second anal fin spine robust, as long as first anal-fin ray.... 3

3a. Body silvery without stripes or dark spot; head profile slightly convex; 55 or more scales along lateral line up to caudal fin base B. ensifera

(eastern Pacific, from Southern Mexico to Peru)

3b. Body with wavy stripes or dots; head profile straight or slightly concave; 46-53 scales along lateral line up to caudal fin base 4

4b. Eyes large, orbital diameter larger than $8 \% \mathrm{SL}$

B. goeldi sp. nov.

(western Atlantic, Brazilian coast)

4a. Eye small, orbital diameter less than $8 \%$ SL 5

5a. 46-49 scales with pores along lateral line up to caudal fin base B. armata

(eastern Pacific, from Gulf of California to Colombia)

5b. 50-53 (rarely 49) scales with pores along lateral line up to caudal fin base

6

6a. Dorsal fin relatively high and head relatively small, height of dorsal fin 1.2-1.5 times the height of the head; height of dorsal fin 1.2-1.5 times the width of the head.

B. veraecrucis

(western Atlantic, Gulf of Mexico)

6b. Dorsal fin relatively low and head relatively large, height of dorsal fin 1.7-2.7 times height of the head; height of dorsal fin 1.6-2.5 times the width of the head .......... B. ronchus

(western Atlantic, Caribbean Sea)

\section{Acknowledgments}

This study was supported by the National Science and Technology Council of the Brazilian Federal Government (CNPq grant no. 300462/2016-6 to APM, 306054/2006-0 to CO, and 300940/2015-7 and 405144/2013-0 to WBW), the Pará State Research Foundation (FAPESPA grant no. ICAAF 017/2016 to APM), and São Paulo State Foundation (FAPESP grant no. 2016/09204-6 to CO). Special thanks are due to two reviewers (Fabio di Dario and Hudson T. Pinheiro) for their critical reading of the manuscript and their valuable suggestions and comments.

\section{References}

Aguilera OA. Los peces marinos del occidente de Venezuela. Acta Biol Venez. 1998; 18(3):43-57.

Angulo A, Garita-Alvarado CA, Bussing WA, López MI. Annotated checklist of the freshwater fishes of continental and insular Costa Rica: additions and nomenclatural revisions. Check List. 2013; 9(5):987-1019.

Barbosa AJB, Sampaio I, Schneider H, Santos S. Molecular phylogeny of weakfish species of the Stellifer group (Sciaenidae, Perciformes) of the Western South Atlantic based on mitochondrial and nuclear data. PLoS ONE [serial on the Internet]. 2014; 9(7):e102250. Available from: https://doi:10.1371/journal.pone. 0102250

Bernal MA, Rocha LA. Acanthurus tractus Poey, 1860, a valid western Atlantic species of surgeonfish (Teleostei, Acanthuridae), distinct from Acanthurus bahianus Castelnau, 1855. Zootaxa. 2011; 2905(1):63-68.

Camargo M, Isaac V. Os peixes estuarinos da região norte do Brasil: lista de espécies e considerações sobre sua distribuição geográfica. Bol Mus Para Emílio Goeldi: Zool. 2001; 17(2):133-57.

Casatti L. Petilipinnis, a new genus for Corvina grunniens Schomburgk, 1843 (Perciformes, Sciaenidae) from the Amazon and Essequibo river basins and redescription of Petilipinnis grunniens. Pap Avulsos Zool. 2002; 42(7):169-81.

Casatti L, Menezes NA. Família Sciaenidae. In: Menezes NA, Buckup PA, Figueiredo JL, Moura RL, editors. Catálogo das espécies de peixes marinhos do Brasil. São Paulo: Museu de Zoologia da Universidade de São Paulo; 2003. p.86-89.

Castro-Aguirre JL, Espinosa Pérez H, Schmitter-Soto JJ. Ictiofauna estuarino-Lagunar y vicaria de México. Mexico: IPN; Limusa; 1999. (Série Biotechnologías).

Cervigón F. Tiburones, peces batoideos y peces óseos. In: Cervigón F, Cipriani R, Fischer W, Garibaldi L, Henrickx M, Lemus AJ et al., editors. Guía de campo de las especies comerciales marinas y de aguas salobres de la costa septentrional de Sur América. Rome: FAO; 1992. p.163-456. (Fichas FAO de identificatión de especies para los fines de la pesca).

Cervigón F. Los peces marinos de Venezuela. Miranda: Fundación Científica Los Roques; 1993.

Chao LN. A basis for classifying western Atlantic Sciaenidae (Teleostei: Perciformes). U.S. Department of Commerce; 1978. (NOAA Technical Report NMFS Circular; 415).

Chao LN. Sciaenidae: Corvinas, barbiches, bombaches, corvinatas, corvinetas, corvinillas, lambes, pescadillas, roncachos, verrugatos. In: Fischer W, Krupp F, Schneider W, Sommer C, Carpenter KE, Niem VH, editors. Pacífico centro-oriental. Rome: FAO; 1995. p.1427-1518. vol. 3, Vertebrados, pt. 2, 
Peces óseos. (Guía FAO para la Identificación de Especies para los Fines de la Pesca).

Chao LN. Sciaenidae. In: Carpenter KE, editor. The living marine resources of the Western Central Atlantic. Rome: FAO; 2003. p.1583-1653. vol. 3, Bony fishes, pt. 2 (Opistognathidae to Molidae), sea turtles and marine mammals. (FAO species identification guide for fishery purposes and American Society of Ichthyologists and Herpetologists Special Publication; No. 5).

Costa-Silva GJ, Rodriguez MS, Roxo FF, Foresti F, Oliveira C. Using different methods to access the difficult task of delimiting species in a complex neotropical hyperdiverse group. PLoS One. 2015; 10:e0135075. 10.1371/journal.pone.0135075

Drummond AJ, Suchard MA, Xie D, Rambaut A. Bayesian phylogenetics with BEAUti and the BEAST 1.7. Mol Biol Evol [serial on the Internet]. 2012; 29(8):1969-73. Available from: https:// doi.org/10.1093/molbev/mss075

Edgar RC. MUSCLE: multiple sequence alignment with high accuracy and high throughput. Nucleic Acid Res. 2004; 32(5):1792-97.

Figueiredo JL, Menezes NA. Manual de peixes marinhos do sudeste do Brasil, III. Teleostei (2). São Paulo, Universidade de São Paulo, Museu de Zoologia; 1980.

Floeter SR, Gasparini JL. The southwestern Atlantic reef fish fauna: composition and zoogeographic patterns. J Fish Biol. 2000; 56(5):1099-114.

Floeter SR, Rocha LA, Robertson DR, Joyeux JC, Smith-Vaniz WF, Wirtz P, Edwards AJ, Barreiros JP, Ferreira CEL, Gasparini JL, Brito A, Falcón JM, Bowen BW, Bernardi G. Atlantic reef fish biogeography and evolution. J Biogeogr. 2008; 35(1):22-47.

Fricke R, Eschmeyer WN, Fong JD, editors. Eschmeyer's Catalog of fishes: species by family/subfamily [Internet]. [updated 17 Jan 2018; cited XXa]. Available from: http://researcharchive.calacademy.org/research/ichthyology/catalog/ SpeciesByFamily.asp

Fricke R, Eschmeyer WN, Fricke R, van der Laan R, editors. Eschmeyer's Catalog of fishes: genera, species, references [Internet]. [updated 17 Jan 2018; cited XXb]. Available from: http://researcharchive.calacademy.org/research/ichthyology/ catalog/fishcatmain.asp

González Bencomo EJ, Borjas JA, Castillo EC. Ictiofauna del sector San Carlos del Lago de Maracaibo, Venezuela. Boletín del Centro de Investigaciones Biológicas. 1997; 31(2):151-79.

Greenfield DW, Thomerson JE. Fishes of the continental waters of Belize. Gainesville: University of Florida Press; 1997.

Günther A. Catalogue of the acanthopterygian fishes in the collection of the British Museum. London: British Museum Natural History; 1864. vol. 2, Squamipinnes, Cirrhitidae, Triglidae, Trachinidae, Sciaenidae, Polynemidae, Sphyraenidae, Trichiuridae, Scombridae, Carangidae, Xiphiidae.

International Union for Conservation of Nature (IUCN). Standards and Petitions Subcommittee. Guidelines for Using the IUCN Red List Categories and Criteria. Version 12 [Internet]. 2016. Available from: http://www.iucnredlist.org/documents/ RedListGuidelines.pdf/

Itagaki MK, Ohkawara MH, Dias JF, Katsuragawa M. Description of larvae and juveniles of Bairdiella ronchus (Sciaenidae: Teleostei) in southeastern Brazil. Sci Mar. 2007; 71(2):249-57.
Jordan DS. List of fishes collected at Havana, Cuba, in December, 1883, with notes and descriptions. Proc U S Natl Mus. 1886; 9(551):31-55.

Jordan DS, Eigenmann CH. A review of the Sciaenidae of America and Europe. Washington: The Bureau, U.S. Government printing office; 1889. (Annual report of the Commissioner of fish and fisheries; vol. 3).

Jordan DS, Evermann BW. The fishes of North and Middle America: a descriptive catalogue of the species of fish-like vertebrates found in the waters of North America, north of the Isthmus of Panama. Washington: Smithsonian Institution, United States National Museum; 1898. (Bulletin, United States National Museum; No. 47).

Kearse M, Moir R, Wilson A, Stones-Havas S, Cheung M, Sturrock S, Buxton S, Cooper A, Markowitz S, Duran C, Thierer T, Ashton B, Mentjies P, Drummond A. Geneious Basic: An integrated and extendable desktop software platform for the organization and analysis of sequence data. Bioinformatics. 2012; 28(12):1647-49.

Lo PC, Liu SH, Chao LN, Nunoo FKE, Mok HK, Chen WJ. A multigene dataset reveals a tropical New World origin and Early Miocene diversification of croakers (Perciformes: Sciaenidae). Mol Phylogenet Evol [serial on the Internet]. 2015; 88:132-43. Available from: https://doi.org/10.1016/j.ympev.2015.03.025

De La Cruz Agüero J, Martínez MA, Gómez VMC, De La Cruz Agüero G. Catalogo de los peces marinos de Baja California Sur. Ciudad del Mexico: Instituto Politécnico Nacional, Centro Interdiciplinario de Ciencias Marinas; 1997.

Machado LF, Damasceno JS, Bertoncini AA, Tosta VC, Farro APC, Hostim-Silva M, Oliveira C. Population genetic structure and demographic history of the spadefish, Chaetodipterus faber (Ephippidae) from Southwestern Atlantic. J Exp Mar Biol Ecol. 2017; 487:45-52.

Mago-Leccila F. Nuevas adiciones a la ictiofauna de Venezuela. Acta Biol Ven. 1965; 4(13):365-420.

Marceniuk AP, Caires RA, Wosiacki WB, Di Dario F. Conhecimento e conservação dos peixes marinhos e estuarinos (Chondrichthyes e Teleostei) da Costa Norte do Brasil. Biota Neotropica. 2013; 13(4):251-59.

Marceniuk AP, Caires RA, Siccha-Ramirez R, Oliveira C. Review of the Harvestfishes, genus Peprilus (Perciformes: Stromateidae), of the Atlantic coast of South America. Zootaxa. 2016; 4098(2):311-32.

Marceniuk AP, Siccha-Ramirez R, Barthem RB, Wosiacki WB. Redescription of Notarius grandicassis and Notarius parmocassis (Siluriformes; Ariidae), with insights into morphological plasticity and evidence of incipient speciation. Syst Biodivers. 2017; 15(3):274-89.

Marceniuk AP, Caires RA, Machado L, Cerqueira N, Serra RRMS, Oliveira C. Redescription of Orthopristis ruber and Orthopristis scapularis (Haemulidae: Perciformes), with a hybridization zone off the Atlantic coast of South America. Marine Biodiversity. In press.

Marceniuk AP, Burlamaqui TCT, Oliveira C, Carneiro J, Eleres $\mathrm{B}$, Sales JBL. Incipient speciation, driven by distinct environmental conditions, in the marine catfishes of the genus 
Aspistor (Siluriformes, Ariidae), from the Atlantic coast of South America. J Zool Syst Evol Res. 2019; 57:1-18. doi/ full/10.1111/jzs.12261.

Marín G. Ichthyofauna and fisheries of the Unare Lagoon, Estado Anzoategui, Venezuela. Acta Biol Venez. 2000; 20(3):61-92.

Matamoros WA, Schaefer JF, Kreiser BR. Annotated checklist of the freshwater fishes of continental and insular Honduras. Zootaxa. 2009; 2307:1-38.

McEachran JD, Fechhelm JD. Fishes of the Gulf of Mexico. University of Texas Press. Austin; 2005.

McEachran JD, Fechhelm JD. Fishes of the Gulf of Mexico. Austin: University of Texas Press; 2005. vol. 2, Scorpaeniformes to Tetraodontiformes.

Meek SE, Hildebrand SF. The marine fishes of Panama. Field Museum of Natural History, Zoölogical Series. 1925; 15(226):331-707.

Menezes NA, Buckup PA, Figueiredo JL, Moura RL. Catálogo das espécies de peixes marinhos do Brasil. Universidade de São Paulo, São Paulo; 2003.

Menezes NA, Figueiredo JL. Manual de peixes marinhos do sudeste do Brasil. IV. Teleostei (3). São Paulo, Museu de Zoologia da USP; 1980.

Miranda-Ribeiro A. 1913-15 Fauna brasiliense. Arq Mus Nac. Rio de Janeiro 1915; 17:1-679.

Nelson JS, Crossman EJ, Espinosa Pérez H, Findley LT, Gilbert CR, Lea RN, Williams JD. Common and scientific names of fishes from the United States, Canada, and Mexico. 6th ed. Maryland: American Fisheries Society; 2004. (Special Publication; 29).

Page LM, Espinosa-Pérez H, Findley LD, Gilbert CR, Lea RN, Mandrak NE, Mayden RL, Nelson JS. Common and scientific names of fishes from the United States, Canada, and Mexico. 7th ed. Bethesda: American Fisheries Society; 2013. (Special Publication; 34).

Pearson DL, Hamilton AL, Erwin TL. Recovery plan for the endangered taxonomy profession. Bioscience. 2011; 61(1):58-63.

Petuch EJ. Biogeography and biodiversity of Western Atlantic mollusks. Boca Raton: CRC Press; 2013.

Pinheiro HT, Rocha LA, Macieira RM, Carvalho Filho A, Anderson AB, Bender MG, Di Dario F, Ferreira CEL, Figueiredo Filho J, Francini Filho R, Gasparini JL, Joyeux J-C, Luiz OJ, Mincarone MM, Moura RL, Nunes JACC, Quimbayo JP, Rosa RS, Sampaio CLS, Sazima I, Simon T, Vila-Nova DA, Floeter SR. South-western Atlantic reef fishes: Zoogeographical patterns and ecological drivers reveal a secondary biodiversity centre in the Atlantic Ocean. Divers Distrib. 2018; 24(7):951-65.

Poey F. Synopsis piscium cubensium: Catalogo razonado de los peces de la isla de Cuba. Habana: Imprenta de la Viuda de Barcina y Compa; 1868.

Pons J, Barraclough T, Gomez-Zurita J, Cardoso A, Duran D, Hazell S, Kamoin S, Sumlim WD, Vogler AP. Sequence-based species delimitation for the DNA taxonomy of undescribed insects. Syst Biol. 2006; 55(4):595-609.

De Queiroz K. Species concepts and species delimitation. Syst Biol. 2007; 56(6):879-86.
Rambaut A, Suchard M, Xie D, Drummond. A. Tracer BEAST. 2014; Updated 17 Jan. 2018. Available from: http://tree.bio. ed.ac.uk/software/tracer/

R Core Team. R: A language and environment for statistical computing. R Foundation for Statistical Computing, Vienna, Austria. 2013; http://www.R-project.org

Ribeiro AO, Caires RA, Mariguela TC, Pereira LHG, Hanner R, Oliveira C. DNA barcodes identify marine fishes of São Paulo State, Brazil. Mol Ecol Res. 2012; 12(6):1012-20.

Robertson DR, Cramer KL. Defining and dividing the greater Caribbean: insights from the biogeography of shorefishes. PLoS ONE [serial on the Internet]. 2014; 9(7):e102918. Available from: doi:10.1371/journal.pone.0102918

Robins CR. Distributional patterns of fishes from coastal and shelf waters of the tropical western Atlantic. Rome: FAO; Symposium on Investigations and Resources of the Caribbean Sea and Adjacent; 1971. (Papers on Fisheries Resources; No. 2).

Rocha LA. Patterns of distribution and processes of speciation in Brazilian reef fishes. J Biogeogr. 2003; 30(8):1161-71.

Roux C. 1973. Poissons continental brésilien. téléostéens du plateau Résultats scientifiques des campagnes de la Calypso, X. Ann1s Inst. Océanogr. Paris, 1973; 49:23-207.

Santos S, Hrbek T, Farias IP, Schneider H, Sampaio I. Population genetic structuring of the king weakfish, Macrodon ancylodon (Sciaenidae), in Atlantic coastal waters of South America: deep genetic divergence without morphological change. Mol Ecol. 2016; 15(14):4361-73.

Sasaki K. Phylogeny of the family Sciaenidae with notes on its zoogeography (Teleostei, Perciformes). Mem Fac Fish, Hokkaido Univ. 1989; 36(1-2):1-137.

Silva WC, Marceniuk AP, Sales JBL, Araripe J. Early Pleistocene lineages of Bagre bagre (Linnaeus, 1766) (Siluriformes: Ariidae), from the Atlantic coast of South America, with insights into the demography and biogeography of the species. Neotrop Ichthyol [serial on the Internet]. 2016; 14(2):e150184. Available from: http://dx.doi.org/10.1590/1982-0224-20150184

Smith CL, Tyler JC, Davis WP, Jones RS, Smith DG, Baldwin CC. Fishes of the Pelican Cays, Belize. Atoll Res Bull. 2003; 497:1-88.

Tamura K, Stecher G, Peterson D, Filipski A, Kumar S. MEGA6: Molecular Evolutionary Genetics Analysis version 6.0. Mol Biol Evol. 2013; 30(12):2725-29.

Vazzoler AEAM. Ictiofauna da baia de Santos. Sciaenidae (Percoidea, Percomorphi). Bolm Inst Oceanogr S Paulo. 1970; 1918(1):11-26.

Vinson C, Gomes G, Schneider H, Sampaio I. Sciaenidae fish of the Caeté Riverestuary, Northern Brazil: mitochondrial DNA suggests explosive radiation for the Western Atlantic assemblage. Genet Mol Biol. 2004; 27(2):174-80.

Ward RD, Zemlak TS, Innes BH, Last PR, Hebert PD. DNA barcoding Australia's fish species. Philos Trans R Soc London, Biol Sci; 2005; 360(1847):1847-57.

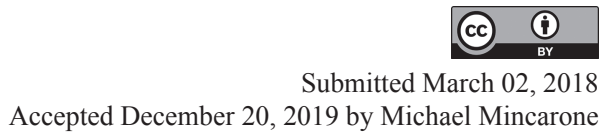

Submitted March 02, 2018 Accepted December 20, 2019 by Michael Mincarone 